\title{
THE ALKALINE AND SHOSHONITIC INTRUSIVES IN THE REGION OF THE TAQUAREMBÓ PLATEAU, SOUTHERN BRAZIL: ARE THEY GENETICALLY RELATED?
}

\author{
MARIA DO CARMO P. GASTAL
}

\begin{abstract}
RESUMO AS INTRUSÕES ALCALINA E SHOSHONÍTICA NA REGIÃO DO PLATO DO TAQUAREMBÓ, SUL DO BRASIL: ELAS SÃO GENETICAMENTE RELACIONADAS? O maciço granítico Santo Antônio e o complexo anelar Leões representam, respectivamente, as associações magmáticas de natureza shoshonítica e alcalina na região do Platô do Taquarembó, extremo sul do Brasil. As duas associações incluem rochas vulcânicas cogenéticas, e todo o conjunto faz parte dos eventos magmáticos do final do Ciclo Brasiliano (540-620 Ma) no Escudo Sul-riograndense. O maciço granítico Santo Antônio é composto por monzogranitos e quartzo monzonitos, enquanto o complexo anelar Leões

é composto por monzodioritos e quartzo sienitos. A comparação de elementos maiores e traço das duas associações, incluindo também rochas básicas a intermediárias de outras regiões do escudo, revela que seus magmas parentais são originados a partir do manto litosférico levemente enriquecido em elementos incompatíveis, e que as diferenças se devem a particularidades na gênese e na evolução em câmaras magmáticas diferentemente posicionadas na crosta. No modelamento de elementos traço para fusão parcial no manto superior partiu-se da composição do manto litosférico empobrecido por eventos prévios de fusão e subseqüentemente enriquecido em elementos incompatíveis. Os resultados indicam que baixos percentuais de fusão parcial (2-3\%) e variações na proporção de granada/clinopiroxênio desta fonte são suficientes para explicar os principais contrastes nos padrões de ETR das rochas menos diferenciadas de ambas associaç̃es, embora a maior diversidade de magmas parentais shoshoníticos seja também sugerida. Este modelamento não explica o comportamento de alguns elementos LIL e HFS, como Ba, Rb, Y, Zr, Nb e Ti. Da mesma forma, as divergências constatadas são dificilmente ajustadas à influência diversificada de subducção, ou mesmo, à assimilação de segmentos infracrustais pelos magmas basálticos. A mistura dos magmas mantélicos com líquidos produzidos por fusão parcial de rochas infracrustais, com diferentes composições e em diferentes condições, é capaz de acomodar as peculiaridades composicionais dentro de cada e entre as duas associações. Nos tipos shoshoníticos, tais contrastes são explicados pela mistura com líquidos derivados de rochas básicas a intermediárias por fusão parcial em condições hidratadas e pressões da base da crosta, ou em condições de subsaturação em água e pressões do manto superior. Para os tipos alcalinos, estariam envolvidas composições mais evoluídas e similares aos granulitos regionais, e o menor grau de fusão parcial em condições de subsaturação em água. Desta forma, a transição dos eventos magmáticos shõshonítico-alcalino pode ser pensada como devida a mudanças nas regiões fontes mantélicas e crustais associadas a modificações na tectônica regional, com o predomínio de regime extensional durante a produção de magmas alcalinos. No platô do Taquarembó, os contrastes composicionais nos magmas parentais das duas intrusões, produzidos desta forma, foram posteriormente ampliados durante sua evolução em câmaras magmáticas diferentemente posicionadas na crosta. A intrusão shoshonítica representa os primeiros episódios magmáticos evoluídos a partir de câmaras magmáticas menores e mais profundas na crosta, enquanto a intrusão alcalina e rochas vulcânicas correlatas registram a diferenciação em câmaras magmáticas maiores e mais rasas, caracterizadas pela diversidade de processos de fracionamento.
\end{abstract}

Palavras-chave: magmatismo alcalino (super)saturado em silica, shoshonítico, magmatismo do Ciclo Brasiliano, interação manto-crosta

ABSTRACT The Santo Antônio granitic massif and the Leões ring complex represent, respectively, the shoshonitic and alkaline magmatic associations in the Taquarembó Plateau, southernmost Brazil. The two associations include cogenetic volcanic rocks, and both represent the late magmatic events of the Brasiliano Cycle (620-540 Ma) in the Sul-riograndense shield. The Santo Antônio granitic massif includes monzogranites and quartz-monzonites, whereas monzodiorites and quartz-syenites are exposed in the Leões ring complex. The comparison of major and trace elements of the two associations, including also samples from other regions of the shield, reveals that their parental magmas are derived from a slightly enriched lithospheric mantle; the differences among them are due to the genetic particularities and to the evolution in crustal magma chambers at distinct depths. Trace-element modeling for upper mantle partial melting is made from the composition of a lithospheric mantle depleted by previous melting events and later enriched in incompatible elements. The results indicate low-degree of melting (2-3\%) of a source with distinct garnet/clinopyroxene ratios for producing parental magmas of the two associations. However, a more diversified origin of the shoshonitic rocks can be also suggested. The behavior of some LILE and HFSE, such as Ba, Rb, Y, Zr, Nb and Ti is not entirely explained by the modeling. In the same way, the observed divergences are hardly adjusted to the influence of subduction, or to the bulk assimilation of lower crustal segments by mantle-derived magmas. The mixing of basaltic magmas with partial melts produced from lower crustal rocks with distinct compositions at different conditions is able to justify the compositional peculiarities between and within the two associations. In the shoshonitic types, the geochemical characteristics are explained by mixing with partial melts derived from basic-to-intermediate compositions either under more hydrous conditions at lower crust pressures, or under fluid-absent conditions at upper mantle pressures. More felsic compositions, similar to the enclosing granulites, and a lower melting degree under fluid-absent conditions would be involved in the genesis of the alkaline rocks. Then, the shoshonitic-alkaline transition can be though as being due to modifications in the mantle and lower crust source regions, reflecting probably a change in the regional tectonic setting, with the predominance of extensional regime during the genesis of the alkaline magma. Particularly for the two plutons of the Taquarembó plateau, the divergence in the composition of the two parental magmas produced in this way was further enhanced during its evolution in magma chambers differently placed at shallower levels in the crust. The shoshonitic massif represents the first magmatic episode, evolved from a smaller and deeper-seated chambers, while the alkaline intrusive and the correlated volcanic rocks register the differentiation in a larger and shallower chamber, where the diversity of fractionation processes predominates.

Keywords: silica-(over)saturated alkaline magmatism, shoshonitic, Brasiliano-cycle magmatism, mantle-crust interaction.

INTRODUCTION The Taquarembó Plateau is situated in the southwestern portion of the Sul-riograndense shield, southern Brazil. It is composed of volcanic and plutonic rocks with silica- (over) saturated alkaline, and less often, with shoshonitic affinity (Gastai et al. 1992, Sommer et al 1993, Barros \& Nardi 1994). The alkaline plutonic terms include the Leões ring complex, and the Santo Antônio granitic massif has a shoshonitic affinity. The volcanic rocks were traditionally separated into acid and intermediate terms and referred to as distinct stratigraphic units, the Acampamento Velho and the Hilário Formations, respectively. Both rock groups with contrasting geochemical nature represent the late magmatism of the Brasiliano Cycle, in the western portion of the shield. Recently, these volcanic and plutonic rocks were grouped according to their geochemical nature, either shoshonitic or silica-(over) saturated alkaline but even so, they were thought to be separated by about $100 \mathrm{Ma}$. New geochronological and geochemical data obtained for both associations have shown that these two magmatic events are separated by a shorter period of time (10-40 Ma), and that they had a roughly common mantle source (Remus et al. 1997). Both associations have $\varepsilon N d(600 \mathrm{Ma})$ values (0 to
-3) close to the primitive mantle (Babinski et al. 1996, Lima \& Nardi 1998 ) and, in the $\varepsilon \mathrm{Nd}-\varepsilon \mathrm{Sr}$ diagram, their signatures are compatible with an enriched-mantle source - EM-I (Gastai \& Lafon 1998).

The following questions can then be stated, concerning the petrogenetic relations between the shoshonitic and alkaline magmatic events: if substantial modifications in mantle sources were discarded, what kind of genetic process can explain the evolution of the two compositional trends? Are these processes related to variable degrees of partial melting of comparable mantle reservoirs or can the particular signature on each type of parental magma be ascribed to diverse subduction or crustal participation? This contribution evaluates the main geochemical features of the Leões ring complex and the Santo Antônio granitic massif, particularly the genetic relationship. For the discussion about the origin of the two associations, more basic rocks correlated with them from other regions of the western portion of the shield are also included. The approaches are advanced through geochemical modeling either directed to the possible changes in the mantle melting processes, as the interaction of mantle-derived magmas with lower crustal partial melts. In the volcano-plutonic plateau, the pro- 
gression from shoshonitic to silica-(over) saturated alkaline magmatism through the successive rise and evolution of shallow magma bodies is also discussed.

\section{GEOLOGICAL SETTING Regional Background The}

Precambrian rocks exposed in the state of Rio Grande do Sul include ancient terranes surrounded and intruded by rocks of the Brasiliano Cycle. The eastern sector includes a large volume of granitic rocks formed during distinct tectonic regimes of the same collisional event (Dom Feliciano - $600 \mathrm{Ma}$ ). The western sector has two parts - the Paleoproterozoic granulites, and diverse Neoproterozoic terranes evolved during the early arc-magmatic event - Vila Nova, at about 700 Ma (Fig. 1) (Babinski et al, 1996). Both western domains are intruded by late- to post-orogenic granites and covered by sedimentary and volcanic sequences, which represent a foreland manifestation of the collisional event. The cratonic terrain is restricted to the occurrence of the Santa Maria Chico Granulitic Complex in the west, as proposed Fernandes et al (1995).

The late magmatism is represented by partially contemporaneous shoshonitic and silica-(over)saturated alkaline intrusive and volcanic rocks, and by poorly known high-K calc-alkaline granites (Fig. 1A). The shoshonitic volcanic and plutonic rocks have ages of 620-590 Ma, and are referred as the Lavras do Sul shoshonitic association (Lima \& Nardi 1998). In the homonym region, it is represented by thick volcanogenic deposits with trachyandesites and basaltic trachyandesites, which are intruded by quartz-monzodiorites, monzonites, quartz-monzonites and monzogranites of the Lavras do Sul intrusive complex, and by spessartites. The alkaline intrusive rocks, with ages of about $580-$ $540 \mathrm{Ma}$, belong to the Saibro intrusive suite (Nardi \& Bonin 1991). Besides dominantly metaluminous granites, peralkaline granites, quartz-syenites, monzodiorites and diorites are also present in this suite. Acid volcanic rocks (rhyolites and trachytes), part of the Acampamento Velho Formation, are cogenetic with these intrusive rocks. The alkaline volcanic and plutonic rocks are grouped into the Ramada (over)saturated alkaline association (Gastai 1997). The basic-to-intermediate plutonic rocks of this association are subdivided in two groups based on major- and trace element contents. The dominant type occurs in the center-southwestern sector and is represented by monzodiorites and quartz-monzodiorites of the Leões ring complex - LRC, and by microdiorites of the Armeiras dikes - AD (Fig. 1 A). This group has a more typical mildly alkaline nature. The other includes diorites and quartz-diorites associated to the Ramada granitic complex, and are transitional between sub-alkaline and mildly alkaline compositions.

GEOLOGY OF THE TAQUAREMBÓ PLATEAU The country rocks of this volcanic plateau include Paleoproterozoic granulites and Neoproterozoic, high-K calc-alkaline granitoids (Fig. 2). Trachyandesites form the base of the volcanic rocks and are concordantly overlain by the acid ones. Acid volcanic rocks have commenditic composition and contain interlayered trachytic-to-rhyolitic lavas and pyroclastic rocks (Sommer et al 1993). The Santo Antônio granitic massif is intrusive into, and genetically correlated with the basal trachyandesites in the northern portion of the plateau. The Leões ring complex is a small intrusion related to the upper trachytes, on the southeastern border of this plateau.

The Santo Antônio granitic massif (SAGM) is an elliptical body elongated in a NW-SE direction (Fig. 2). It has dominant monzogranites, and subordinate quartz-monzonites and granodiorites (Barros \& Nardi 1994). In the less evolved fades, the mafic phases include augite-to-diopside, Mg-hornblende and Mg-biotite. The reinterpretation of the $\mathrm{Rb}$-Sr whole-rock (WR) isotopic data for seven samples of the SAGM presented by Barros \& Nardi (1994), yielded an age of 645 $\pm 58 \mathrm{Ma}(2 \mathrm{~s})$ and a $\left({ }^{87} \mathrm{Sr} /{ }^{86} \mathrm{Sr}\right)_{\mathrm{i}}$ of $0.70461 \pm 0.00026(2 \mathrm{~s})$, with MSWD of 2.31 (Gastai et al 1998).

The Leões ring complex (LRC) has a monzodioritic core surrounded by quartz-syenites, which form arcuate dykes about $1-1.5 \mathrm{~km}$ wide (Fig. 2). The most basic terms include orthopyroxene-bearing monzodiorite-to-monzogabbros, and subordinate quartz-monzodiorites. In these fades, Fe-enstatite, augite, along with Mg-hornblende, labradorite/andesine, and ilmenite/titanomagnetite are the dominant phases. The quartz-syenites are intrusive into the core fades, and they are related to at least two distinct pulses. The main quartzsyenitic fades, on the west side, is intrusive into the basal units of the acid volcanic rocks. It has a metaluminous composition and contains augite and Fe-barroisite. The younger microsyenitic fades occurs on the east-southeast side and is closely related to the upper trachytic units. It has a weakly peralkaline composition, containing aegirineaugite and Fe-ritcherite. A Rb-Sr age of $566 \pm 44 \mathrm{Ma}(2 \mathrm{~s})$ and a

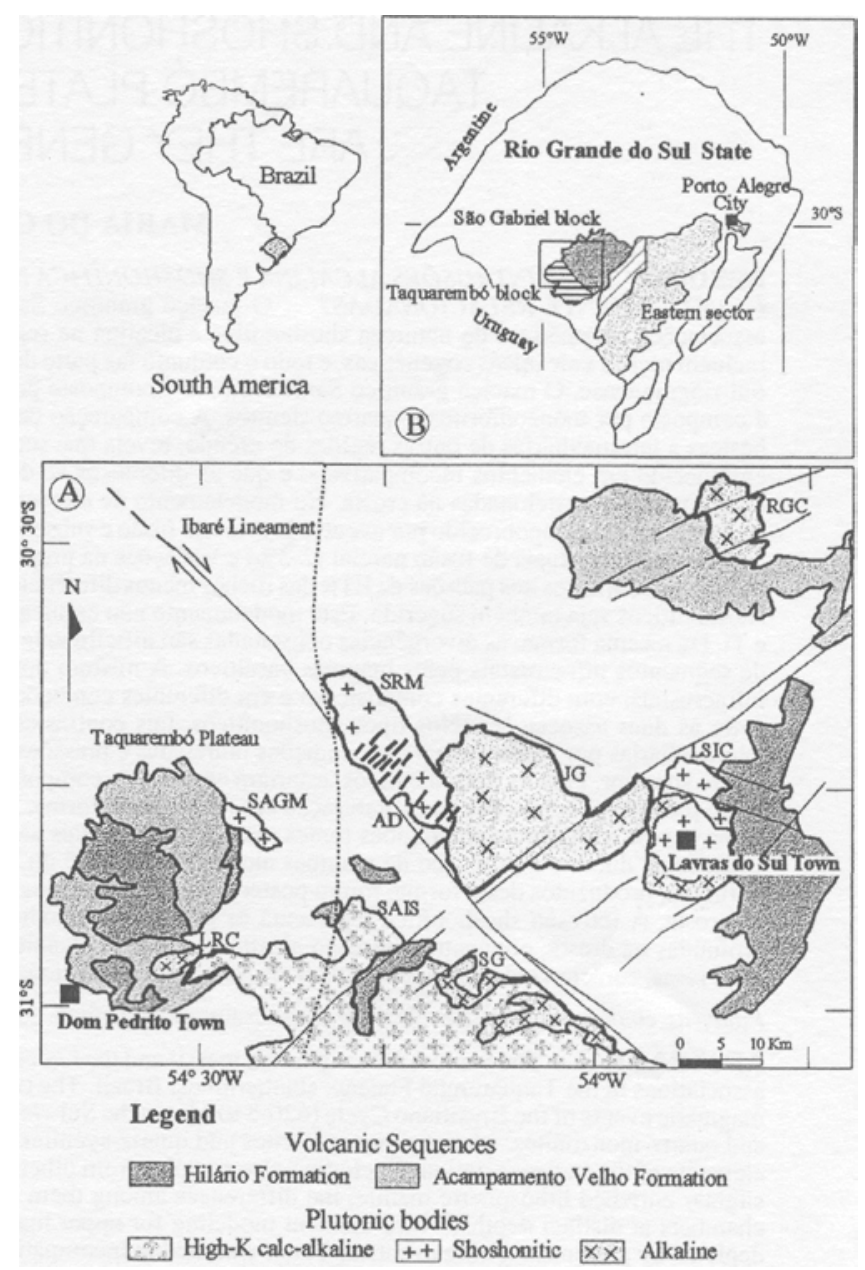

Figure 1 - Location map of the center-southwestern region of the Sul-riograndense Shield, showing the main occurrences related to late magmatic events of the Brasiliano Cycle (A): SAIS - Santo Afonso Intrusive Suite; LSIC - Lavras do Sul Intrusive Complex; SRM - Santa Rita Monzogranite; SAGM - Santo Antônio Granitic Massif; RGC Ramada Granitic Complex; JG -Jaguari Granite; $\boldsymbol{S G}$ - Saibro Granite; LRC - Leões Ring Complex; and AD - Arme iras Dikes. Lines of the main fault, and dotted line highlights the boundary of the cratonic domain of the west, as proposed Fernandes et al. (1995). The main geotectonic unity of the shield are shown in $(\boldsymbol{B})$, where the detailed area is outlined.

$\left({ }^{87} \mathrm{Sr} r{ }^{86} \mathrm{Sr}\right)_{\text {i }}$ of $0.70485 \pm 0.00028(2 \mathrm{~s})$, with MSWD of 18.5 , was obtained for twelve samples (WR) of this complex (Gastai et al 1998). The older age of the SAGM $(645 \pm 58 \mathrm{Ma})$ compared with that of the Leões ring complex ( $566 \pm 44 \mathrm{Ma})$ was questioned by Gastai et al. (1998). The main arguments are the similarity in the arrangement of the $\mathrm{Rb}-\mathrm{Sr}$ analytical data for the two intrusions and the fact that only one sample of the SAGM, which departs from the others, accounts for the oldest age. Perhaps, the age interval between the two magmatic events is not as large as revealed by $\mathrm{Rb}-\mathrm{Sr}$ isotopic systematic. This is also confirmed by U-Pb isotopic data in the Lavras do Sul region (Remus et al. 1997), where the shoshonitic granites have an age of 592

$\pm 5 \mathrm{Ma}(2 \mathrm{~s})$ and the alkaline ones, $580 \pm 7 \mathrm{Ma}(2 \mathrm{~s})$. The main mineralogical characteristics of representative rocks of the two associations are summarized in Table 1. Besides the two intrusive rocks (SAGM and LRC) of the Taquarembó plateau, shoshonitic volcanic rocks from the Lavras do Sul region are also included. Detailed petrographic descriptions of these rocks are provided respectively by Barros \& Nardi (1994), Gastai et al. (1998) and Lima \& Nardi (1998).

PETROLOGICAL AND GEOCHEMICAL FEATURES OF THE SHOSHONITIC ROCKS AND THE ALKALINE INTRUSIVE Representative major- and trace element data of samples from the SAGM and LRC are given in Table 2. In addition, the less differentiated microdiorites of the Armeiras dikes (AD) are also shown 
in chemical diagrams and table 2. Since the three AD-samples have no much evidence of hybridism, they are taken as representative of parental alkaline magmas (Figs. 3 through 5).

The Leões ring complex (LRC) forms a bimodal association with total alkalis increasing up to $66-67 \% \mathrm{SiO}_{2}$ and it follows a typical silica-(over)saturated alkaline trend (Fig. $3 \mathrm{~A}$ ). The monzodiorites are sodic, with $\left(\mathrm{Na}_{2} \mathrm{O}-2\right)>\mathrm{K}_{2} \mathrm{O}$. The syenitic facies have moderate-to-high HFSE and REE abundance, being classified as A-type (Collins et al 1982) and within-plate (Pearce et al. 1984) granites. The Santo Antônio granitic massif (SAGM) has lower alkalis content than the LRC-syenites (Fig. $3 \mathrm{~A}$ ). The high $\mathrm{Ba}$ and $\mathrm{Sr}$ contents, and the moderate values of $\mathrm{Zr}$, LREE, $\mathrm{TiO}_{2}$ and $\mathrm{P}_{2} \mathrm{O}_{5}$ of this massif support a shoshonitic affinity, and it was included in the Lavras do Sul shoshonitic association by Barros \& Nardi (1994). Due to the lack of available chemical data for trachyandesites of the volcanic plateau that could be directly related to SAGM, the basic-to-intermediate rocks of the shoshonitic association were taken from the Lavras do Sul region (Lima \& Nardi 1998). In principle, the similarity among incompatible trace-element ratios of more basic alkaline rocks from the two next localities, Taquarembó and Ibaré (Fig. $1 \mathrm{~A}$ ), supports that correlation. This indicates a roughly similar mantle signature and so implies a relatively homogeneous subcrustal lithosphere in the region. Then, the similarity in composition of shoshonitic parental magmas from there is also a workable option. In the TAS diagram, the shoshonitic rocks overlap those from the alkaline association in the most basic compositions, but have $\mathrm{Na}_{2} \mathrm{O}<\mathrm{K}_{2} \mathrm{O}$, and show no pronounced increase in alkalis at intermediate silica contents (Fig. 3A).

Basic-to-intermediate Rocks and the Nature of Parental Magmas MAJOR AND TRACE ELEMENTS The most basic terms of the shoshonitic and alkaline associations are already evolved, typically with $52-55 \%$ wt. $\mathrm{SiO}_{2}$, and they have enriched $\left({ }^{87} \mathrm{Sr} /{ }^{86} \mathrm{Sr}\right) \mathrm{j}$ isotopic ratios of about 0.704-0.705 (Lima \& Nardi 1998, Gastai et al 1998). The evolved composition of these rocks suggests that although they are mantle-derived, they may have undergone further differentiation in the crust. Shoshonitic volcanic rocks, compared with the alkaline rocks, have a more primitive nature as suggest the high concentrations of compatible elements, such as $\mathrm{Mg}, \mathrm{Cr}$ and $\mathrm{Ni}$, at comparable silica values; this is valid only for the less evolved samples with $~ 52$ wt. $\% \mathrm{SiO}_{2}$ (Table 2). In some of shoshonitic basaltic trachyandesites and trachybasalts, the high $\mathrm{MgO}$ values could have resulted from cumulative olivine and clinopyroxene, as postulated Lima \& Nardi (1998). However, samples of these rocks with well-defined cumulate characteristics are not shown in the diagrams. Differentiation trends up to trachyandesites (shoshonites), possibly controlled by an olivine and augite-dominated fractionating assemblage (OC), are marked by pronounced decrease in the abundance of compatible elements, as Mg, Ni and $\mathrm{Cr}$ (Table 2). The produced trachyandesites thus have $\mathrm{MgO}$ contents slightly lower than the LRC-monzodiorites at similar $\mathrm{SiO}_{2}$ values (Fig. 4). This behavior, along with the highest $\mathrm{FeO}_{\mathrm{t}}$ abundance in the monzodiorites, results in parallel trends as $\mathrm{FeO} / \mathrm{MgO}$ ratios for both associations, with the alkaline being more Fe-enriched (Fig. 3C). The potassic nature of the more basic shoshonitic rocks is emphasized by elevated and constant values of the $\mathrm{K}_{2} \mathrm{O} / \mathrm{Na}_{2} \mathrm{O}$ ratio, while in the equivalent rocks of alkaline affinity, $\mathrm{K}_{2} \mathrm{O} / \mathrm{Na}_{2} \mathrm{O}$ ratios are lower and increase suddenly with the differentiation (Fig. 3B).

Other differences between the two rock series are related to the $\mathrm{Al}_{2} \mathrm{O}_{3}$ contents (higher in the shoshonitic association), and to the $\mathrm{TiO}_{2}$ $\mathrm{P}_{2} \mathrm{O}_{5}$ and $\mathrm{MnO}$ values, which are more elevated in the alkaline types (Table 2 and Fig. 4). The alkaline magmas are saturated in apatite and its evolution accompanies the isotherm of about $1000^{\circ} \mathrm{C}$. This is consistent with the early crystallization of apatite in the LRC-monzodiorites, which occurs in euhedral to subhedral, well-developed crystals. In the shoshonitic ones, on the contrary, the apatite saturation is only reached at the end of the crystallization in the most evolved trachyandesites. Such behavior can be attributed to different retention of accessory phases during the generation of the two parental magmas, either due to the melting degree or to heterogeneity of the involved sources. The same could be said for the $\mathrm{TiO}_{2}$ contents but, here, the two trends rather reflect changes in the fractionation of oxide phases. A Ti-rich magnetite is required in the differentiation of the shoshonitic parental magma, whereas in the alkaline one the oxide phases have a more varied behavior during the crystallization. At least in some LRC-monzodiorites, fractionation of Ti-magnetite is postponed until about 57 wt.\% $\mathrm{SiO}_{2}$, as suggest the high and constant values of $\mathrm{FeO}_{t}$, and the slight increase in $\mathrm{TiO}_{2}$ contents (Fig. 4).

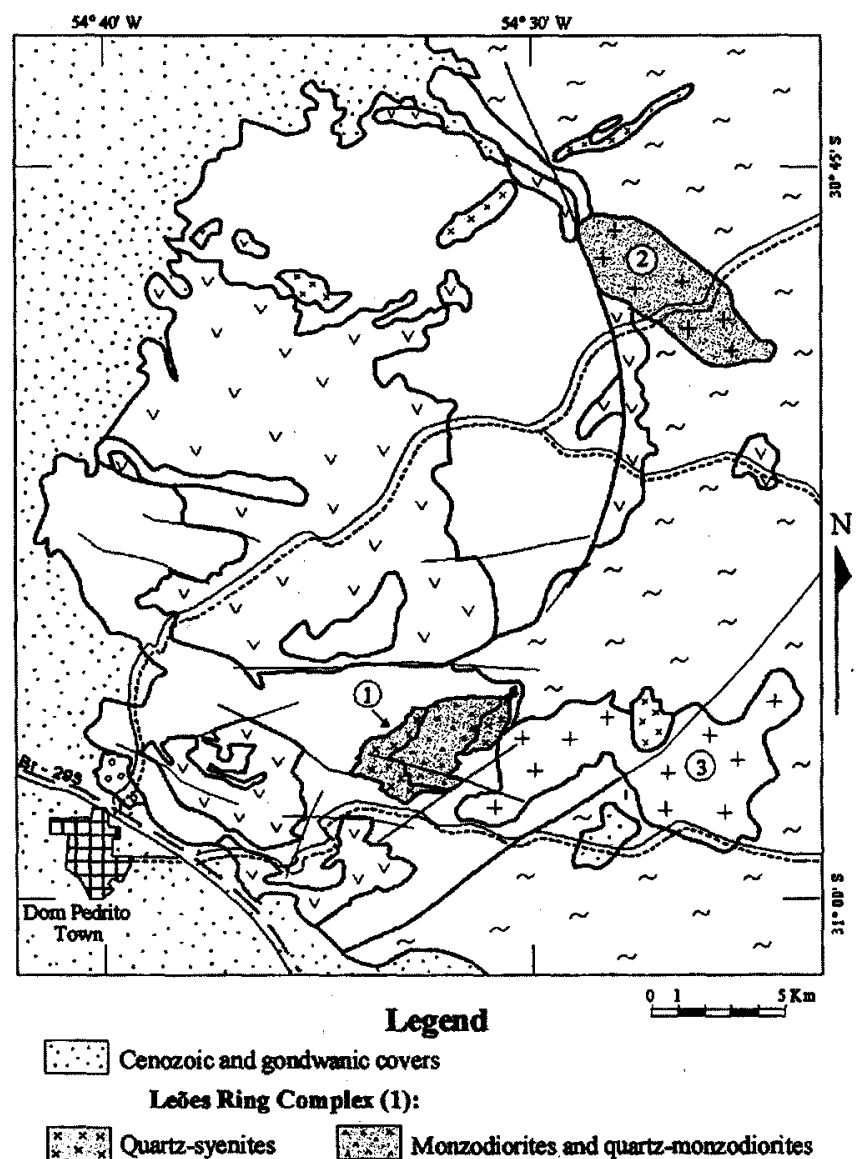

$\square$ Acid Volcanic Sequence

+ Calc-alkaline to shoshonitic granitoids: (2) Santo Antônio

Granitic Massif, and (3) Santo Afonso Intrusive Suite

$v^{v} v$ Trachy-andesites and trachy-andesitic tuffs

$\because \because$ Maricá Formation

\section{$\approx \sim$ Santa Maria Chico Granulitic Complex \\ Lithologic contact}

- Faults

Figure 2 - Geological map of the Taquarembó Plateau, modified from Szubert et al. (1976). Sommer (1994) and Gastai et al. (1998) updated the southern portion: (1) Leões Ring Complex; (2) Santo Antônio Granitic Massif; and (3) Santo Afonso Intrusive Suite.

The major-element contents for the alkaline rocks, despite the dispersion observed for most oxides, are consistent with a plagioclase and clinopyroxene-dominated fractionating assemblage, and minor amounts of orthopyroxene and Ti-poor magnetite (Gastai et al. 1998). The large dispersion in the values of some oxides could be indicating the evolution of distinct pulses of the same parental magma, as suggested in $\mathrm{FeO}_{\mathrm{t}}$ and $\mathrm{CaO}-\mathrm{SiO}_{2}$ plots (Fig. 4). This would imply the influence of processes other than mineral fractionation, as contamination with crustal segments. Moreover, in the quartz-monzodioritic facies composed by hybrid rocks, the anomalous high values of oxides as $\mathrm{TiO}_{2}$ and $\mathrm{P}_{2} \mathrm{O}_{5}$ are ascribed to chemical selective diffusivity associated to magma mixing (Gastai 1997). The differences in the composition of DA-microdiorites, compared with LRC-monzodiorites, could be partly attributed to their less differentiated nature and to a higher melting degree. Contrarily to the alkaline, the shoshonitic association shows well-defined trends, except for $\mathrm{MgO}$ and $\mathrm{Al}_{2} \mathrm{O}_{3}$ (Fig. 4). The strong increase in the $\mathrm{Al}_{2} \mathrm{O}_{3}$ content can be reflecting absence of plagioclase in the fractionated phases up to intermediate rocks, which agrees with an OC assemblage controlling the evolution of this suite as proposed by Lima \& Nardi (1998).

Significant differences for trace elements among the more basic rocks of the two associations are related to the behavior of $\mathrm{Y}, \mathrm{Rb}, \mathrm{Sr}$, M- and HREE (Figs. 5-6). The alkaline types have more elevated Y 
and lower $\mathrm{Rb}$ values, showing a more pronounced increase for both elements with the progress of the differentiation. In the shoshonitic rocks, these two elements stay constant or slightly increase. The $\mathrm{Rb}$ behaves in a similar, though less pronounced way to that of the $\mathrm{K}_{2} \mathrm{O} / \mathrm{Na}_{2} \mathrm{O}$ ratios (Fig. 3B) and this could be related to the varied potassic-sodic nature of the two rock suites. The contrasts in $\mathrm{Y}$ contents can be attributed to the diversified retention of accessory phases as apatite in the source. This is corroborated by the behavior of $\mathrm{P}_{2} \mathrm{O}_{5}$ (Fig. 4), but the participation of others mineral phases, such as amphibole or garnet, could be also postulated. The Sr content of more basic rocks of the two suites is similar, and the differences are at the intermediate compositions (Table 2, Fig. 5). This behavior is analogous to that of the $\mathrm{Al}_{2} \mathrm{O}_{3}$ and would reinforce the already reported role of plagioclase. The similarity in the $\mathrm{Zr}, \mathrm{Ba}$ and, in some extend, $\mathrm{Nb}$ concentration in these rocks indicates a roughly common composition of the mantle sources for both associations. This conclusion is also supported by incompatible element ratios, such as $\mathrm{Ce} / \mathrm{Nb}, \mathrm{Ba} / \mathrm{La}, \mathrm{Zr} / \mathrm{Nb}$ and $\mathrm{Y} / \mathrm{Nb}$ (Table 2). In both associations, the more basic rocks have a relatively LREE-enriched pattern (Fig. 6). Differences in the REE patterns are due to the stronger depletion in M- and HREE, particularly for Gd to Er, exhibited by the shoshonitic types (Figs. 6A-C, Table 2). Thus, the REE patterns also highlight the contrast in the participation of mineral phases, such as amphibole or garnet, in the origin of the two parental magmas.

NATURE OF THE PARENTAL MAGMAS Several constraints for the genesis of the magmas of the two suites can be drawn from the foregoing discussion:

1. Their parental magmas were originated from a roughly similar mantle source; the LREE enrichment and the moderate values of some HFSE imply an enriched lithospheric mantle, though the previous depletion would be also required for explaining the low values of incompatible elements as $\mathrm{Nb}$.

2. The major- and trace element contents of the silica-poor rocks in both associations primarily reflect two types of crystallization histories, and this implies at least two distinct parental magmas.
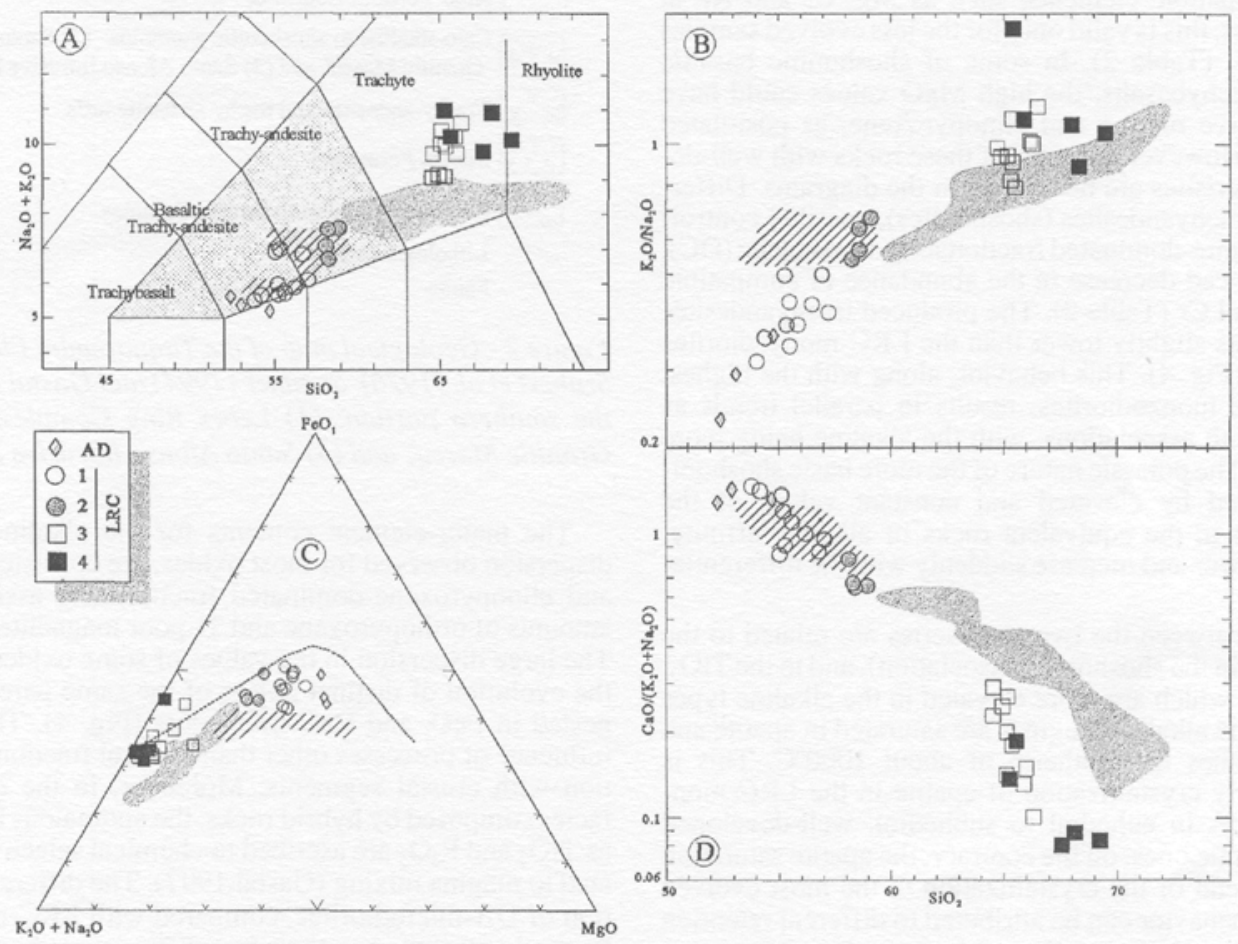

3. In addition, the compositional contrasts between the two types of more basic rocks allow presupposing a varied participation of residual mineral phases in their genesis. Then, the differences in Ti, P, Y, Mand HREE contents would be explained by the effect of accessory mineral phases, such as apatite, garnet, amphibole or Ti-oxides. The greater the participation of these minerals, the lower the melting degree in the origin of the shoshonitic parental magma. However, similar concentrations of elements as LREE, $\mathrm{Zr}$ and $\mathrm{Ba}$ in the two types of more basic rocks are in contradiction with this assumption, mainly when a common mantle source is assumed for both associations. Thus, these restrictions lead to search the answer for genesis of the magmas of the two suites on small-scale heterogeneity in the mantle source, or upon other processes as mantle-crust interaction. This latter alternative

Table 1 - Sumary of the main mineralogical characteristics of representative rocks of the two associations.

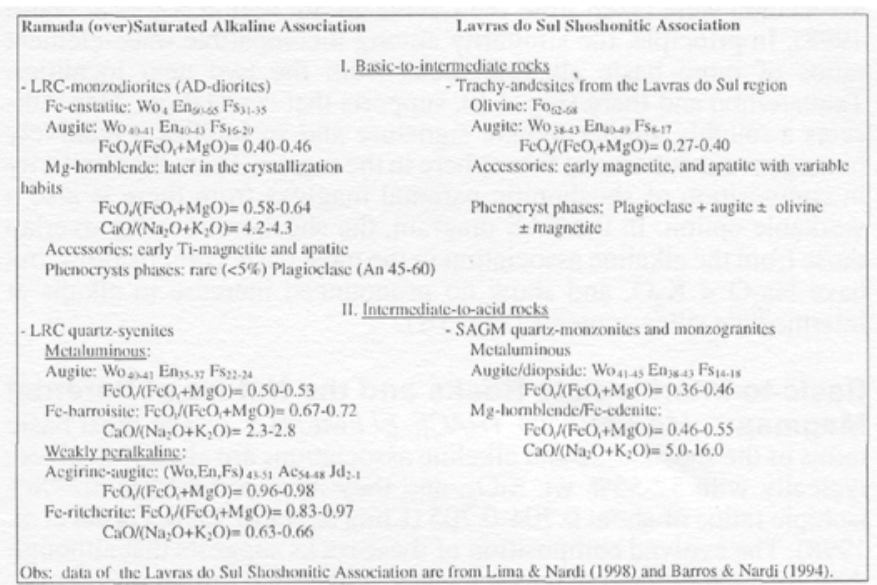

Obs: data of the Lavras do Sul Shodsonitic Association are from Lima \& Nardi (1998) and Barros \& Nardi (1994).

Figure 3 - Total alkalis versus $\mathrm{SiO}_{2}$, with classification boundaries after Le Maitre (1989) (A); $\mathrm{K}_{2} \mathrm{O} / \mathrm{Na}_{2} \mathrm{O}$ ratio versus $\mathrm{SiO}{ }_{2}$ (B); AFM diagram with the limit between the tholeiitic and calc-alkaline trends (Irvine \& Baragar 1971) for reference (C); and calc-alkaline ratio versus $\mathrm{SiO}_{2}$ (D) (all in anhydrous basis). AD -Armeiras microdioritic dikes; LRC - Leões Ring Complex: 1 -monzodiorite-to-monzogabbros; 2 - hybrid quartz-monzodiorites; 3 - metaluminous quartz-syenites; and 4 - weakly peralkaline alkali feldspar-quartz-microsyenites; Shoshonitic association: stippled field for basaltic trachy-andesites and shoshonites from the Lavras do Sul's region (Lima \& Nardi 1998); and gray, for the Santo Antônio Granitic Massif (Barros \& Nardi 1994). 
is more suitable to adapt the possible effect of the residual and accessory mineral phases, as discussed Hildreth \& Moorbath (1988). 4. Different water contents of the two parental magmas can induce the two crystallization histories, during their differentiation in magma chambers deeper in the crust. The greater proportion of mafic phases as olivine, clinopyroxene and Ti-magnetite, with almost no plagioclase, in the fractionating assemblage of the more basic shoshonitic rocks would imply an evolution under more hydrous conditions. A more anhydrous composition could be postulated for the alkaline parental magma, where a typical POC (plagioclase, olivine/orthopyroxene, and clinopyroxene) fractionating assemblage controls their evolution. These conclusions agree with experimental results for similar mafic compositions. At pressure lower than $8 \mathrm{kbar}$, more elevated water contents reduce the amount of plagioclase, and thus increase the proportion of olivine and clinopyroxene over plagioclase (Baker \& Eggler 1987, Meen 1987); at moderated $f \mathrm{O}_{2}$, increased $\mathrm{PH}_{2} \mathrm{O}$ expands the stability of magnetite over silicate minerals (Groove \& Sisson 1991). In this way, the genetic processes for the two associations must also explain the varied water contents of their parental magmas. Again, the two referred hypotheses (small-scale heterogeneity or mantle-crust interaction) are suitable, but the interaction of mantle-derived magmas with lower crust partial melts is more attractive. At least, this can explain the presence of orthopyroxene instead of olivine in the LRCmonzodiorites, since the crustal partial melt is relatively anhydrous, as postulated by Gastai (1997). The increase the $\mathrm{fO}_{2}$ and silica activity, but does not change the $f \mathrm{H}_{2} \mathrm{O}$, favoring the stability of orthopyroxene over olivine (Lindsley et al. 1990).
Theoretical Rayleigh fractionation sequences were plotted (Fig. 7), for crystallization of individual phases and relevant mineral assemblages using distribution coefficients $(\mathrm{Kd})$ compiled by Rollison (1993). The more basic rocks in the two associations form an array of increasingly negative $\mathrm{Eu}$ anomaly when plotted against fractionation indices such as $\mathrm{SiO}_{2}$ (Fig. 7A). Both trends are approximately subparallel to the vector equivalent to a PCO assemblage (50:30:20), and they can be superimposed on this vector if the starting point is placed at different $\mathrm{SiO}_{2}$ and $\mathrm{Eu} / \mathrm{Eu}^{*}$ values. A parental magma more primitive, with no negative $\mathrm{Eu}$ anomaly but high $\mathrm{SiO}_{2}$ content, is required to derive the shoshonitic trend; a larger plagioclase effect is suggested for the genesis of the alkaline one, corroborating earlier conclusions (Figs. 4 and 5). In theory, differences in the beginning of the plagioclase fractionation, due to its sensitivity to $\mathrm{PH}_{2} \mathrm{O}$, in two batches of the same primary magma could explain the observed contrasts between the two associations. Any model in this sense would imply substantial variations in the water content in a magma chamber deeper-seated in the crust, and this alone is not easy to be drawn. However, it should do if the changes in the water content were associated to distinct crustal melts mixed with the basaltic magma. In the evolution of the shoshonitic association, another problem is given by the $\mathrm{Eu} / \mathrm{Eu}^{*}$ ratios (Fig. $7 \mathrm{~A}$ ), since they do not support the referred delay in the plagioclase fractionation up to trachyandesites. This requires other solutions for explain the observed geochemical contrasts, such as that involving the interaction with lower crust partial melts.

The Y-Rb plot (Fig. 7B) shows that the compositional contrasts between the two groups of more basic rocks are certainly related to diversified amount of garnet in the sources. The shoshonitic silica-poor

Table 2 - Major and trace elements for representative samples of the two magmatic associations

\begin{tabular}{|c|c|c|c|c|c|c|c|c|c|c|c|c|c|}
\hline & \multicolumn{5}{|c|}{ Idurras do Sul Shoshonitic Asscriation } & \multicolumn{8}{|c|}{ Ramada Alkaline (over)Saturated Association } \\
\hline & \multicolumn{2}{|c|}{ (5) } & \multicolumn{3}{|c|}{\begin{tabular}{|c|} 
SAGM \\
\end{tabular}} & \multirow{2}{*}{\begin{tabular}{|c|} 
AD \\
$286 \mathrm{~A}$
\end{tabular}} & \multicolumn{7}{|c|}{ I.RC } \\
\hline & BAA-07 & AN106 & CB-3 & $\mathrm{Cl338}$ & Chi3hit & & M532 & M536 & $\mathbf{M 4 2 3}$ & $\mathbf{5 5 3 7}$ & S48 & $\mathbf{S 3 1 3}$ & MS363 \\
\hline $\mathrm{SiO}_{2}$ & 52.00 & 53.60 & 62.9) & 64.42 & 71.98 & 51.16 & 52.00 & 53.18 & 54.87 & 62.39 & 63.64 & 64.96 & 68.69 \\
\hline $\mathrm{TiO}_{2}$ & 1.00 & 0.90 & 0.84 & 0.72 & 0,41 & 2.08 & 1.37 & 1.52 & 1.23 & 0.98 & 0.87 & 0.73 & 0.56 \\
\hline $\mathrm{Al}_{2} \mathrm{O}_{3}$ & 14.25 & 18.60 & 14.16 & I5.73 & 13.98 & 13,34 & 15.76 & 14.82 & 15.33 & 13.88 & 15.016 & 14.80 & 13.33 \\
\hline $\mathrm{Fe}_{2} \mathrm{O}_{3}$ & 2.50 & 2.40 & 2.21 & 2.85 & 1.03 & 3.89 & 3.98 & 3.44 & 3.48 & 3.18 & 2.48 & 3.77 & 3.83 \\
\hline $\mathrm{FeO}$ & 6.19 & 4.68 & 2.80 & 2.07 & 1.79 & 6.96 & 5.09 & 5.13 & 5.45 & 2.68 & 2.72 & 1.63 & 1.56 \\
\hline Mno & 0.10 & 0.07 & 0.07 & 0.07 & 0.03 & 0.16 & 0.13 & 0.14 & 0.13 & 0.20 & 0.17 & 0.17 & 0.19 \\
\hline $\mathrm{MgO}$ & 8.20 & 3.20 & 1.58 & 1.16 & 0.55 & 5.58 & 4.60 & 3,81 & 4.78 & 1.69 & 0.73 & 0.32 & 0.15 \\
\hline $\mathrm{CaO}$ & 7.00 & 6.50 & 3.38 & 2.70 & 1.52 & 7.51 & 7.71 & 7.94 & 6.35 & 2.17 & 1.98 & 1.05 & 0.84 \\
\hline $\mathrm{Na}_{2} \mathrm{O}$ & 3.70) & 4.20 & 4.45 & 4.45 & 3.91 & 4.04 & 4.04 & 4.18 & 4.85 & 4.52 & 5.39 & 4.69 & 4.87 \\
\hline $\mathrm{K}_{2} \mathrm{O}$ & $2.00)$ & 2.90 & 3.33 & 3.84 & 4.67 & 1.18 & 1.26 & 1.59 & 2.08 & 4.26 & 4.43 & 5.73 & 5.17 \\
\hline $\mathrm{P}_{2} \mathrm{O}_{3}$ & 0.20 & 0.36 & 0.43 & 0.34 & 0.14 & 0.77 & 0.70 & 0.71 & 0.76 & 0.14 & 0.25 & 0.15 & 0.07 \\
\hline $\mathrm{CO}_{2}$ & - & -- & -- & -. & - & 0.20 & .. & - & 0.18 & $\cdots$ & 0.95 & 0.95 & 0.45 \\
\hline LOI & $2 .(0)$ & 2.30 & 1.18 & 0.61 & 0.30 & 1.77 & 1.88 & 1.37 & 0.65 & 1.96 & 0.44 & 0.51 & 0.03 \\
\hline $\mathrm{H}_{2} \mathrm{O}^{\circ}$ & .. & -- & 0.39 & 0.39 & 0.26 & 0.21 & 0.37 & 0.31 & 0.25 & 0.31 & 0.27 & 0.36 & 0.19 \\
\hline Tutal & 99.14 & 99.71 & 99.70 & 99.35 & 101.57 & 98.85 & 98.89 & 98.14 & 100.21 & 98.36 & 98,43 & 98.87 & 99.39 \\
\hline $\mathrm{Cr}$ & 180 & 56 & -. & -. & -- & -. & 87 & 56 & 82 & -. & -. & -- & -. \\
\hline $\mathrm{Ni}$ & 167 & 20 & .. & $\because$ &.. & 78 & 69 & 51 & 37 & -. & -. & -. & -- \\
\hline $\mathbf{R b}$ & 60 & 51 & 72 & 115 & 140 & 17 & 27 & 48 & 35 & 86 & 43 & 55 & 65 \\
\hline Ba & 1085 & $13(0)$ & $193 i$ & 19012 & 1078 & 795 & 1138 & $15 i 4$ & 1941 & 1790 & 1511 & 556 & 159 \\
\hline $\mathrm{Sr}$ & 710 & 1270 & 784 & 710 & 336 & 476 & 769 & 645 & 662 & 235 & 132 & $<30$ & $<30$ \\
\hline Ga & -- & - & 18 & 19 & 12 & 18 & 10 & 10 & 20 & 13 & 24 & 24 & 25 \\
\hline $\mathrm{Nb}$ & 14 & 22 & 28 & 34 & 34 & 21 & 12 & 12 & 19 & 20 & 39 & 33 & 49 \\
\hline $\mathrm{Zr}$ & 280 & 287 & 342 & 318 & 240 & 239 & 274 & 286 & 276 & 345 & $20 !$ & 343 & 548 \\
\hline$Y$ & 25 & 20) & 43 & 47 & 52 & 39 & 32 & 36 & 36 & 53 & $5 t$ & 51 & 84 \\
\hline La & 52.03 & 51.12 & 68.23 & 84.92 & 59.07 & 38.21 & 55.63 & $79.00)$ & 60.31 & -. & 63.46 & 66.33 & 145.00 \\
\hline $\mathrm{Ce}$ & 91.05 & 94.02 & 133.70 & 155.40 & 113.70 & 90.87 & 119.90 & 168.30 & 138.00 & -. & $143 .(0)$ & 154.00 & 287.00 \\
\hline Nd & 40,81 & 44.41 & 50.90 & 56.57 & 37.81 & 45.92 & 56.24 & 77.58 & 58.32 & -. & 66.82 & 68.10 & 126.00 \\
\hline $\mathrm{Sm}$ & 7.20 & 6.85 & 7.12 & 7.92 & 5.38 & 8.58 & 9.66 & 13.17 & 10.23 & - & 11.47 & 10,40 & 18.75 \\
\hline Eu & 1.94 & 1.82 & 1.72 & 1.78 & 0.97 & 2.27 & 2.26 & 2.82 & 2.25 & - & 3.07 & 2.17 & 1.53 \\
\hline Gd & 5.00 & 4.95 & 4.16 & 4.50 & 3.08 & 6.66 & 6.20 & 8.17 & 7.44 & ". & 8.02 & 6.77 & 12.29 \\
\hline Dy & 2.78 & 2.83 & $3.00)$ & 3.20 & 2.52 & 6.53 & 4.99 & 7.90 & 5.91 & -- & 7.56 & 6.80 & 10.15 \\
\hline Ho & 0.35 & 0.54 & 0.60 & 0.65 & 0.52 & 1.30 & 0.92 & 1.59 & 1.21 & -- & 1.58 & 1,36 & 2.07 \\
\hline $\mathrm{Er}$ & 1.03 & 1.58 & 1.45 & 1.73 & 1.37 & 3.51 & 2.09 & 4.35 & 3.37 & -- & 4.20 & 3.62 & 5.80 \\
\hline Yh & 0.89 & 1.45 & 1.20 & 1.41 & 1.47 & 3.15 & 1.49 & 3.20 & 3.04 & -. & 3.68 & 3.66 & 5.49 \\
\hline Lu & 0.12 & 0.20 & 0.17 & 0.20 & 0.22 & 0.39 & 0.17 & 0.38 & 0.41 & -. & 0.53 & $0.51)$ & 0.75 \\
\hline IREE & 203.2 & 209.77 & 272.33 & 318.28 & 226.11 & 207.39 & 259.58 & 366.44 & 290.50 & - & 313.39 & 323.72 & 614.83 \\
\hline $\mathrm{Cc} / \mathrm{Yb}_{\mathrm{N}}$ & 26.46 & 16.77 & 28.82 & 28.50 & 20.00 & 7.46 & 20.81 & 13.60 & 11.74 & $\cdots$ & 10.05 & 10.88 & 13.52 \\
\hline Eu/Eu* & 0.94 & 0.91 & 0.89 & 0.83 & 0.67 & 0.89 & 0.84 & 0.77 & 0.75 & -- & 0.93 & 0.74 & 0.29 \\
\hline $\mathrm{Cc} / \mathrm{Nb}$ & 6.50 & 4.27 & 4.78 & 4.57 & 3.34 & 4.32 & 9.99 & 14.02 & 7.26 & -. & 3.67 & 4.67 & 5.86 \\
\hline $\mathrm{Ba} / \mathrm{La}$ & 20.85 & 25.43 & 28.30 & 22.40 & 18.25 & 20.81 & 20.46 & 19.04 & 32.18 & .. & 23.81 & 8.38 & 1.10 \\
\hline $\mathrm{Ba} / \mathrm{Nb}$ & 77.50 & 59.09 & 68.96 & 55.94 & 31.71 & 37.86 & 94.83 & 125.33 & 102.16 & 89.50 & 38.74 & 16.85 & 3.24 \\
\hline $\mathrm{Zr} / \mathrm{Nb}$ & $20.00)$ & 13.04 & 12.21 & 9.35 & 7.06 & 11.38 & 22.83 & 23.83 & 14.53 & 17.25 & 5.15 & 10.39 & 11.18 \\
\hline Y/Nh & 1.79 & 0.91 & 1.54 & 1.38 & 1.53 & 1.86 & 2.66 & 3.00 & 1.89 & 2.65 & 1.31 & 1.54 & 1.71 \\
\hline K/Rb & 276.72 & 472.04 & 383.93 & 277.19 & 276,91 & 576.23 & 387.40 & 274.97 & 493.34 & 411.20 & 855.23 & 864.83 & 660.27 \\
\hline $\mathrm{Rh} / \mathrm{Zr}$ & $0.2 t$ & 0.18 & 0.21 & 0.36 & 0.58 & 0.07 & 0.10 & 0.17 & 0.13 & 0.25 & 0.21 & 0.16 & 0.12 \\
\hline Y/Rh & 0.42 & 0.39 & 0.60 & 0.41 & 0.37 & 2.29 & 1.18 & 0.75 & 1.03 & 0.62 & 1.19 & 0.93 & 1.29 \\
\hline $\begin{array}{l}\text { Notes: B } \\
\text { Barros \& }\end{array}$ & & & & & - & & \& Nardi & $\overline{988): S A}$ & SM gavrl & & nite and & monzogra & $\begin{array}{l}\text { anite after } \\
\text { WR major } \\
\text { versidade } \\
\text { y flame } \\
\text { luctively }\end{array}$ \\
\hline
\end{tabular}


rocks form a homogenous group at lower $\mathrm{Y}$ and higher $\mathrm{Rb}$ values, while the alkaline equivalent types show a greater dispersion of points in this diagram. As for crystallization, this would be only resolved by varied clinopyroxene/plagioclase ratios in the fractionating assemblage. Regardless, the pronounced decrease in $\mathrm{Rb}$, promoting the analytical data dispersion of the LRC-rocks in this plot, can be resulting of contamination with a $\mathrm{Rb}$-poor lower crust.

In summary, the theoretical models allow to question the evolution of the two associations only based on distinct water contents of similar primary magmas. They also show that each parental magma is produced differently from a roughly common mantle source. At the same time, solutions for explain the compositional contrasts in the more basic rocks between and within the two associations led to conclude by the importance of processes involving mantle-crust interaction.

Felsic Terms and the Evolution of the Two Magmatic Trends GEOCHEMICAL TRENDS The separation of felsic terms of the two magmatic suites in the Taquarembó region is clear as for major and trace elements, especially $\mathrm{CaO}$, alkalis, $\mathrm{MgO}, \mathrm{MnO}$ $\mathrm{P}_{2} \mathrm{O}_{5}$, Sr and $\mathrm{Ba}$ (Figs. 3 through 5). The two granitoids form parallel trends in TAS, AFM and calc-alkaline ratio versus $\mathrm{SiO}_{2}$ diagrams. A more alkaline signature of the LRC quartz-syenites compared with the SAGM is clearly illustrated in these diagrams, and also by the slightly incompatible behavior of $\mathrm{Zr}$ (Fig. 5). The SAGM shows higher Sr (Fig 5 ), and more fractionated patterns and lower REE contents than the LRC (Fig. 6). Diversified composition of amphibole and clinopyroxene of the two groups of felsic rocks reinforces the geochemical contrasts, with a more calcic composition being found in the SAGM (Table 1). The two granitoids are also separated in Ri- $\mathrm{R}_{2}$ diagram (Fig $8 \mathrm{~A}$ ), which emphasizes the differences in $\mathrm{CaO}, \mathrm{MgO}$ and alkalis contents. In this diagram, the quartz-syenites correspond to the less evolved granitic terms of the alkaline suite, whereas the SAGM departs from them and is classified as tardi-orogenic. Nonetheless, both plot as within-plate granites in $\mathrm{Rb}-(\mathrm{Y}+\mathrm{Nb})$ plot (Fig. 8B). Thus, the geochemical features indicate also distinct evolutionary trends for the two granitoids, but a common or closely related source for both could be suggested considering mainly the similarities in HFSE.

The broadly similar REE patterns, with the evolution toward felsic types marked by an increasingly negative $\mathrm{Eu}$ anomaly (Fig. 6), and the constancy in some incompatible trace-element ratios (Table 2), allow to relate both LRC-facies groups mainly by processes of fractional crystallization (FC). Major-element modeling substantiated by traceelement tests provides a reasonable solution to derive the quartzsyenites from the monzodiorites. It is required the fractionation of about $54.9 \%$ of an assemblage composed by $21.2 \%$ OPX, $6.4 \%$ CPX, $60.1 \%$ PL (An 47.5), 6.1\% of magnetite, 3.6\% of ilmenite and $2.5 \%$ of apatite ( $\mathrm{Sr}^{2}$ of 1.82) (Gastai 1997). The divergence between this model and that for the evolution among the monzodioritic facies is due to the proportion and composition of pyroxenes and plagioclase. This was attributed, by Gastai et al (1998), to two concurrent factors: distinct contamination degrees, and varied depths at which the differentiation of similar monzodioritic liquids had occurred. Then, whereas monzodioritic facies represents the magma evolved at a deeper level in the magma chamber, the trend up to quartz-syenites corresponds to the evolution of a more contaminated basic magma at a shallower level. The great depletion in compatible elements, such as $\mathrm{CaO}, \mathrm{MgO}, \mathrm{Sr}$ and $\mathrm{Ba}$, in the LRC quartz-syenites evidences the higher effectiveness of differentiation at shallow levels, with the major hole of plagioclase within the fractionated phases. The result of mass-balance calculations reinforces this conclusion. The best solution for the evolution among quartz-syenites involves the fractionation of $13.9 \%$ of an assemblage composed by $21.4 \% \mathrm{HB}, 74.7 \%$ PL (An 30) and 3.8\% of ilmenite ( $\mathrm{Sr}^{2}$ of 0.14) (Gastai 1997). However, the larger dispersion of some trace elements, such as $\mathrm{Nb}$ and $\mathrm{Rb}$ (Fig. 5), in these rocks implies that the FC cannot be the only process influencing the magma evolution. Such effect could be ascribed to the influence of volatile phases or to contamination with wall rocks during their differentiation. The contamination concurrent with FC is corroborated by the decreasing trend for $\mathrm{P}_{2} \mathrm{O}_{5}$, which crossovers the isotherm lines (Fig. 4). If the granulitic wall rocks are taken as contaminant, this should also explain the abrupt decrease in $\mathrm{Rb}$ and $\mathrm{Nb}$ abundance. On the other hand, the volatile influence in the fractionation of the two quartz-syenitic facies is substantiated by changes in the composition of mafic phases (Tab. 1); thus, a volatile buildup coincides with the gap in the composition of clinopyroxene and the predominance of amphibole crystallization.

The transition from the trachyandesites to the SAGM occurs along a more continuous trend, although some modifications in the fraction- ated mineral phases are necessary to justify the behavior of $\mathrm{MgO}, \mathrm{CaO}$, $\mathrm{TiO}_{2}$ and $\mathrm{Ba}$ (Figs. 4,5). The more accentuated shifts of the $\mathrm{P}_{2} \mathrm{O}_{5}, \mathrm{FeO}$ $\mathrm{Y}, \mathrm{Nb}$ and $\mathrm{Zr}$ content between these two terms, however, are stronger suggesting a somewhat distinct parental magma for the SAGM than that of the trachyandesites. Since these shoshonitic volcanic rocks are from the Lavras do Sul region, little differences in the composition of the SAGM-parental magma could be expected. Nevertheless, the main geochemical tendencies are preserved between the two groups of shoshonitic rocks, so that this allows defining a common evolutionary history. Lima \& Nardi (1998) proposed the fractionation of 38\% of an assemblage composed by $81 \%$ PL (An ${ }_{40}$ ), 12\% CPX and $7 \%$ of magnetite $\left(\mathrm{Sr}^{2}\right.$ of 0.17 ), for producing latitic liquids from trachyandesites. Concerning the derivation of the SAGM quartz-monzonites from trachyandesites, this model is consistent with the crystallization vectors in $\mathrm{Y}-\mathrm{Rb}$ plot, but not for $\mathrm{Eu} / \mathrm{Eu}^{*}$ ratios (Fig. 7). The less evolved SAGM-type has lower negative Eu anomaly but at higher $\mathrm{SiO}_{2}$ values, and the more pronounced amphibole participation would be required to derive it from a magma equivalent to the referred trachyandesites. During the evolution of the SAGM-facies, the importance of hornblende in the fractionating assemblage is also supported by the REE patterns (Fig. 6C). Moreover, the more restricted range of variations of $\mathrm{Mg}^{*}$, but a wide one for silica values in this massif (Fig. 4) reinforces these conclusions. The same is shown by the theoretical vectors in figure 7B and by the mass-balance result reported by Barros \& Nardi (1994). In their modeling for the SAGM, it is necessary the fractionation of $49 \%$ of an assemblage including $69 \%$ PL (An 36), 13\% $\mathrm{HB}, 7.5 \%$ BTA, $7.5 \%$ of Ti-magnetite and $2 \%$ of apatite $\left(\mathrm{Sr}^{2}\right.$ of 0.27$)$. Then, these evidences allow suggesting that the SAGM evolved from a parental magma roughly similar to the trachyandesites, through a hornblende- and plagioclase-dominated fractionating assemblage. However, the derivation of the SAGM from a more distinct shoshonitic parental magma than the trachyandesites could be also postulated based on $\mathrm{Eu} / \mathrm{Eu}^{*}-\mathrm{SiO}_{2}$ and $\mathrm{La} / \mathrm{Yb}_{\mathrm{N}}-\mathrm{Yb} \mathrm{b}_{\mathrm{N}}$ plots (Figs. 7A and 9).

EVOLUTIONARY HISTORIES OF THE TWO ASSOCIATIONS The geochemical trends of the two associations show that some distinctive features of their parental magmas are enhanced in the more evolved facies. This can be reported to two factors: the distinct water contents of the melts and the diversified conditions of their evolution in crustal magma chambers. The compositional zoning between the LRC quartzsyenites and the correlated acid volcanic rocks is comparable with the typical stratification of an epizonal magma chamber associated to cauldron subsidence (Lipman 1984). The greater effectiveness of crystal-liquid fractionation along with more intense activity of volatile phases in such chamber accounts for the more extensive compositional gap between the two groups of LRC-facies. The monzodiorites represent the liquid evolved in the lower portions while the quartz-syenites those at the upper levels. Furthermore, the contamination with granulitic rocks seems to have been very important during the LRC-evolution, and it would have produced diversified effects in the two facies groups. This overlap of processes makes difficult for reproducing the differentiation through geochemical modeling, especially in the more evolved facies. The central points in the LRC-evolution, despite these shortcomings, are the extreme differentiation, the high-level of the magma chamber submitted to cauldron subsidence and the extensive fractionation of calcic phases as augite and plagioclase.

For the shoshonitic association, the more diversified composition of parental magmas suggested can only be due to the fact of the considered rocks are from different regions. Even so, the complexity in the origin of the shoshonitic magmas is strongly indicated in $\mathrm{La} / \mathrm{Yb}_{\mathrm{N}^{-}}$ $\mathrm{Yb}_{\mathrm{N}}$ plot (Fig. 9). However, the differentiation of the more evolved granitoids as the SAGM seems to have occurred through a less complex set of processes than the LRC. Their main geochemical characteristics reflect the important role of amphibole and magnetite in the fractionation. The early presence of hornblende in the crystallization of the SAGM-facies is decisive to deduce a more elevated $\mathrm{PH}_{2} \mathrm{O}$ than the LRC; according to the experimental results of Johnson \& Rutherford (1989), this should still suggest that the crystallization occurred at pressures higher than 2 kbar.

In summary, the LRC registers the differentiation in a large and shallow magma chamber, where the diversity of high-level fractionation processes predominates. In the SAGM, contrarily, these process types are less effective and thus it preserves the features of the evolution in a smaller and deeper-seated magma chamber, and also the characteristics inherited from a particular genetic process. The plutonic rocks of the Taquarembó plateau would represent then the magmas extracted during successive rise, growth and evolution of epizonal 

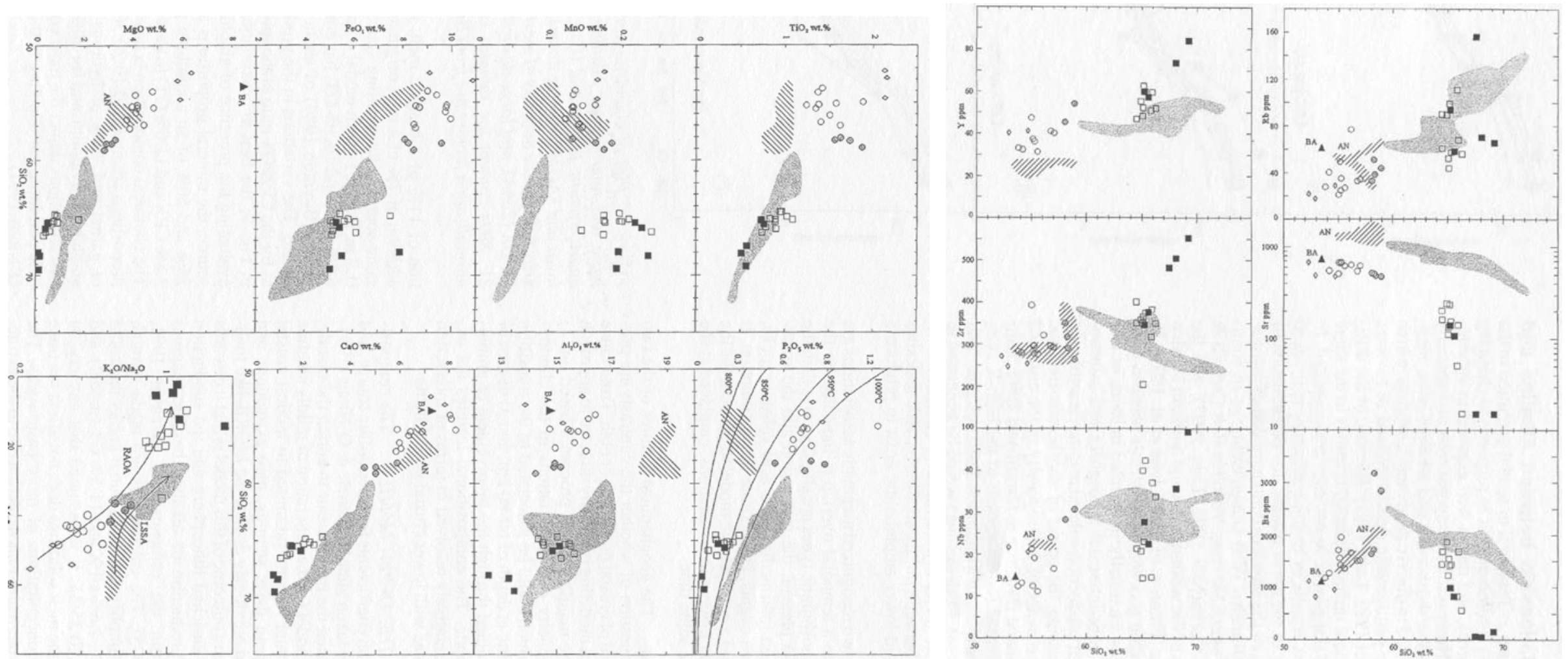

Figure 4 - Marker diagrams, and plot of $\mathrm{K}_{2} \mathrm{O} / \mathrm{Na}_{2} \mathrm{O}$ against $\mathrm{Mg} *$ for samples of the two magmatic

associations; all in anhydrous basis; symbols and fields as in figure 3, and when referred $-B$ A for basaltic trashy-andesite, and AN for trachyandesites (shoshonites) from the Lavras do Sul region (Lima \& Nardi 1998) The isotherms for the apatite solubility, after Harrison \& Watson (1984), are displayed in $\mathrm{P}_{2} \mathrm{O}_{5}-\mathrm{SiO}_{2}$ plot. Mg - Mg-number $=100 * \mathrm{MgO} /(\mathrm{MgO}+\mathrm{FeO})$, on molar proportions and without any $\mathrm{FeO}-\mathrm{Fe} 2 \mathrm{Oj}$ corrections.

$\boldsymbol{R A O A}$ - Ramada Alkaline (over)Saturated Association; and LSSA - Lavras do Sul Shoshonitic Association.

Figure 5 - Plots of $\mathrm{Y}, \mathrm{Zr}, \mathrm{Nb}, \mathrm{Rb}, \mathrm{Sr}$ and $\mathrm{Ba}$ against $\mathrm{SiO}_{2}$ for samples of the two magmatic associations. Symbols and fields, as in figures 3 and 4. 
magma bodies whose affinity changes from shoshonitic to alkaline, as proposed by Gastai et al. (1998).

\section{DISCUSSION Relationship between Alkaline and}

Shoshonitic Rock Suites Temporal or spatial evolution in the nature of magmatic events is a common trait in response to changing tectonic conditions and sources, and this is well exposed in subduction-related environments. However, contemporaneous and spatially associated high-K calc-alkaline/shoshonitic and alkaline basic magmas are another feature reported in diverse geodynamic settings, which have induced an interesting petrogenetic debate (Nelson \& Livieres 1986, Wallace \& Carmichael 1992, Luhr 1997). Because of the difficulty in producing two or more distinct parental magmas in the same region at the same time, several genetic hypotheses are suggested. In some cases, a more complex mantle or tectonic structure is invoked and in others, the upwelling of the upper mantle, the delamination of thickened segments of crust, or the selective contamination of mantlederived magmas with crustal melts. Well-known examples in continental settings are in the Western Mexican Volcanic Belt (Nelson \& Livieres 1986, Wallace \& Carmichael 1992, Luhr 1997), and the mid-Tertiary volcanic fields of the western USA and northern Mexico - Basin and Range Province (Fitton et at. 1991, Leat et al. 1991). In most of these systems, the main geochemical contrasts between calcalkaline and alkaline magmas are usually interpreted in terms of two distinct sources - enriched subcontinental lithosphere and asthenosphere - and the production of subduction-related magmas is attributed to the former. For encompassing the origin of shoshonitic-like and K-rich alkaline rocks, the existence of heterogeneity in the enriched lithospheric mantle is postulated (Wallace \& Carmichael 1992, Luhr 1997). Another view is presented for the genesis of the high-K calcalkaline and alkaline magma types in Mongollon-Datil volcanic field (Davies \& Hawkesworth 1994). Both magmas would be generated in the subcontinental lithosphere under a wide range of conditions, including in times the mixing between mildly alkaline basaltic andesites and melts derived from a mid-lower amphibolitic crust to produce a high-K calc-alkaline trend.

In the studied region, the two recognized magmatic associations are spatially related and, despite a temporal overlap is indicated by the available isotopic data, the shoshonitic types are slightly early than the alkaline. In the Taquarembó plateau, the succession and the stratigraphic concordance between intermediate and acid volcanic rocks, supposedly related to the two events, corroborate this assumption. It is therefore necessary to build a petrogenetic model to account for the generation of two contrasting magmatic associations, emplaced at the same place and almost at the same time.

Source Characteristics The geochemical features of the two parental magmas raise the question of whether the contrasts are produced in the mantle or resulted of crustal processes, or both. To advance this discussion, trace-element modeling is initially directed to approach the possible variations in the mantle melting processes based on: 1) melting degree; 2) heterogeneity due to variations in the clinopyroxene/garnet proportion, which could be associated to the transition from garnet to spinel Iherzolite at depth of $60-80 \mathrm{~km}$; and 3) degree of enrichment of the source, valued through the involvement of amphibole $(<30$ kbar $)$ or phlogopite. The compositional features not explained by the models are tentatively resolved in terms of interaction of the mantle-derived magmas with lower crustal partial melts.

GENETIC MODELING IN THE UPPER MANTLE The compositional parameters and partition coefficients for a peridotitic source, and the basis of the modeling are taken after McKenzie \& O'Nions (1991, 1995). These authors evaluated the mechanisms to enrich the mantle, and proposed a three-stage model for the generation of mildly alkaline basaltic magmas in continental regions submitted to modest crustal extension. They argue that, in these settings, melt extractions and subsequently metasomatised previously deplete the MORB-like mantle by fluids or melts. One main outcome of this model is that it discards the close link between the enriched lithosphere and the subduction signature, as well as the production of alkaline basaltic magmas (OIB-type) exclusively from the asthenosphere (Weaver 1991, McKenzies \& O'Nions 1995). The calculations are made through no-modal batch melting to simplify, taken the initial garnet Iherzolite with $59.8 \%$ OL, $21.1 \%$ OPX, 7.6\% CPX and $11.5 \%$ GT (modal), and eutectic proportions of 10:20:35:35. It is assumed that any crystal fractionation that occurs as the melt solidifies does not affect the trace elements, especially REE concentrations of more basic rocks. The initial source is modified through previous depletion due to the extrac-

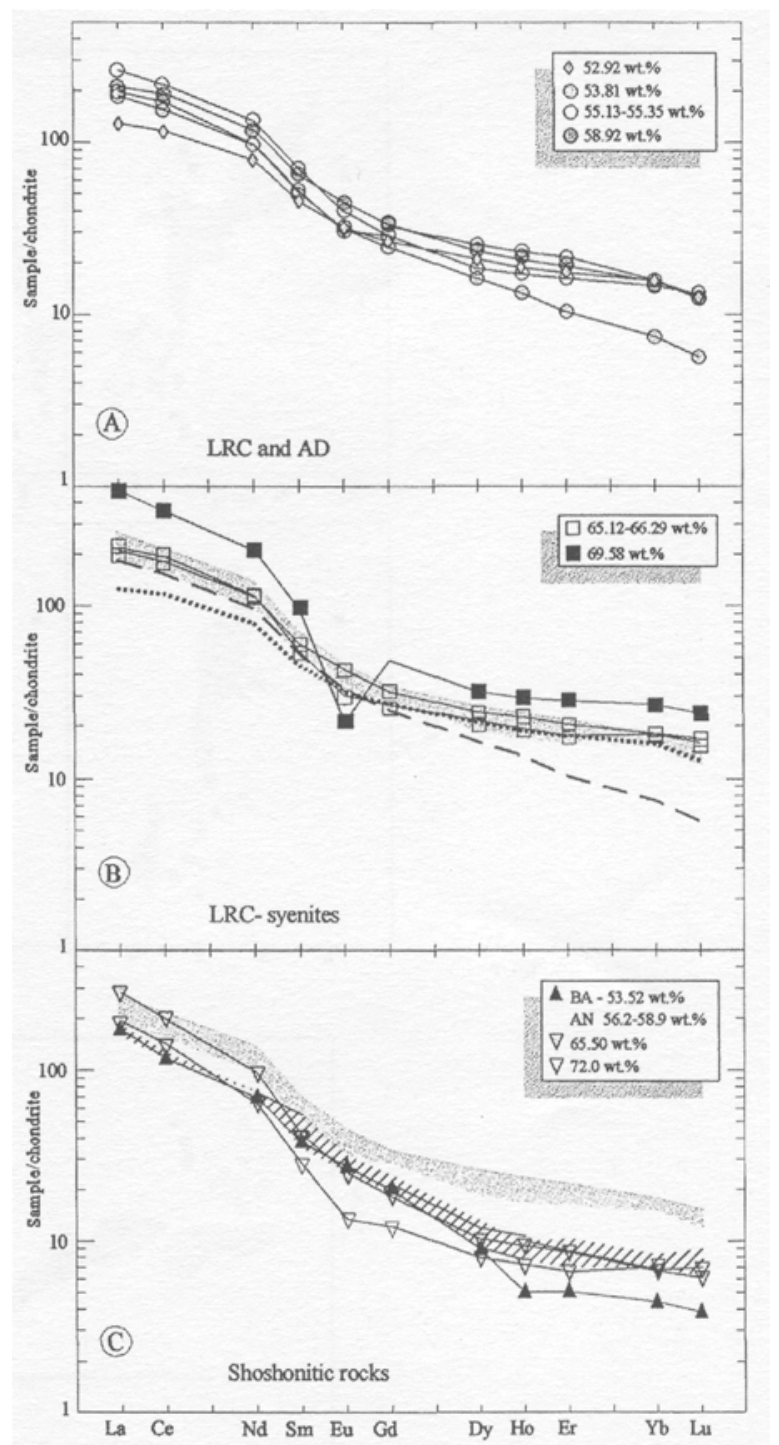

Figure 6 - Plot of chondrite-normalized REE abundance for: $(\boldsymbol{A})$ basic and intermediate alkaline rocks - LRC and $A D$; (B) - LRC quartz-syenitic fades; and $(\boldsymbol{C})$ - shoshonitic rocks: trashy-andesitic lavas and SAGM (triangle down). Symbols as in figures 3 and 4; light gray field for the majority of most basic LRC rocks; in (B), dotted line for DA (286A), and large dashed line for LRC (M532) samples (Tab. 2). $\mathrm{SiO}_{2}$ content for samples is indicated (anhydrous basis), and normalization factors are from Boynton (1984).

tion of $11 \%$ of a basaltic melt, and subsequently enriched with the addition of $7 \%$ of a melt originated by $0.4 \%$ of partial melting of the same source. The resulting source - an enriched lithospheric mantle (L2 in Table 3) - with modal composition of $62.3 \%$ OL, $21.2 \%$ OPX, $6.2 \% \mathrm{CPX}$ and $10.3 \% \mathrm{GT}$, has enrichment factors relative to chondrite values (Boynton 1984) of about 5 times for LREE, and 2 times for HREE. The variations in the produced basaltic melt are then analyzed as for the $\mathrm{CPX} / \mathrm{GT}$ ratio of the source and the melting degree, as shown in Fig. 9; the best approximations are in Table 3 and Fig. 10. For evaluating the presence of amphibole or phlogopite in the Iherzolitic source, the mineral proportions are obtained through the addition of $25 \%$ and $50 \%$ of an amphibole peridotite $(59.9 \%$ OL, $24.7 \%$ OPX, $3.8 \% \mathrm{CPX}$ and $11.6 \% \mathrm{GT}$ ) to the calculated source with $9.3 \%$ of garnet. The chemical composition is taken the same the later, and the eutectic proportions are made 10:10:20:30:30. The resulting source has $6.97 \%$ of garnet and $2.9 \%$ of hydrous phases for addition of $25 \%$ of an amphibole peridotite, and for $50 \%$, respectively, $4.65 \%$ and $5.8 \%$. The two conditions depict the most common range for fractions of amphibole peridotite participating in the origin of basic rocks (McKenzie \& O'Nions 1991). 
Several significant conclusions can be obtained from $\mathrm{La} / \mathrm{Yb}_{\mathrm{N}}-\mathrm{Yb}_{\mathrm{N}}$ plot (Fig. 9). The more basic rocks of the two associations are generated at nearly the same percent of melting, whose value is of about $2 \%-2.5 \%$ for the assumed compositions. This result is consistent with the models of the generation of mildly alkaline basaltic magmas (Jaques \& Green 1980, McKenzie \& O'Nions 1991). The main difference among the diverse groups of more basic rocks in this diagram is unable to be explained by fractional crystallization (FC), whose main vectors are illustrated in the inset of Fig. 9. This is valid either between the two associations (shoshonitic and alkaline), or even among samples of a same association as exemplified by shoshonitic rocks. However, among most of LRC-monzodiorites this could be the explanation for geochemical variations. The same is also valid for the differentiation of spessartites (Lima \& Nardi 1991). In this latter case, the evolution would involve the extensive fractionation of a HP (hornblende-plagioclase) assemblage from a magma produced through a higher melting degree $(5 \% \mathrm{~F})$ from a peridotite with about $6.3 \% \mathrm{GT}$.

Different proportions of garnet/clinopyroxene in the Iherzolitic source seem to be the best solution for explaining the REE patterns of the main groups of more basic rocks from the two associations (Fig. 9 ). About $5 \%$ of garnet are required in the mantle source for producing trachyandesites and $<3-2 \%$ in that source of the alkaline more basic rocks. This contrast in the source composition is corroborated by trace-element ratios as $\mathrm{Y} / \mathrm{Rb}$ and $\mathrm{Rb} / \mathrm{Zr}$, whose values are respectively more elevated and lower in the alkaline compared with shoshonitic more basic rocks (Fig. 7A, Table 2). However, the Ba, LREE, Ti and $\mathrm{P}$ contents of the LRC-monzodiorites are much higher than that expected if the genetic differences relative to the shoshonitic rocks were due only to the lower GT/CPX proportions of the source. So this would be indicating a more enriched lithosphere in the origin of the LRC-parental magma. Nonetheless, a higher degree of enrichment in the source must cause an increment of trace-element abundance in the melt proportional to the degree of its incompatibility; then more elevated values of $\mathrm{Rb}, \mathrm{K}$ and $\mathrm{Nb}$ in the LRC-monzodiorites, which is not observed, should be also expected.

The contrasts in the REE patterns between the two groups of alkaline more basic rocks (AD-microdiorites and LRC-monzodiorites) are easily explained by distinct percents of melting from a similar Iherzolite (Fig. 9). This is also valid for the behavior of $\mathrm{Rb}, \mathrm{Ba}$ and $\mathrm{Sr}$ (Table 2), but again, the $\mathrm{Nb}$ and Ti contents of LRC-rocks are lower than that expected if it were only the melting degree that caused the geochemical differences (Fig. 1 OB). These constraints lead to conclude that, in addition to a lower GT/CPX ratio of the upper mantle source, other conditions are involved in the origin of the alkaline magmatism in this region: a higher melting degree for $\mathrm{AD}$-microdiorites, and a slightly more enriched Iherzolite in the LRC-monzodiorites. Even so, such processes do not resolve all geochemical features, especially in the LRC more basic rocks. In this case, the contrasts could be adjusted with contamination of the alkaline mantle-derived magma in the lower crust. On the other hand, a progressive change at the depth of upper mantle sources could be suggested for the transition from the shoshonitic to alkaline compositions; a lower GT/CPX proportion would imply a shallower depth for the origin of the alkaline magmas.

Concerning the origin of the shoshonitic magmatism, it seems obvious the existence of more than one parental magma, whose differences could be attributed either to the melting degree, presence of amphibole, or to the GT/CPX proportions in the peridotitic source, as shown in $\mathrm{La} / \mathrm{Yb}_{\mathrm{N}}-\mathrm{Yb}_{\mathrm{N}}$ plot (Fig. 9). This is particularly relevant for basaltic trashy-andesite and trashy-andesite, because the $\mathrm{La} / \mathrm{Yb}_{\mathrm{N}}, \mathrm{Yb}_{\mathrm{N}}$ and $\mathrm{Eu} / \mathrm{Eu}^{*}$ values are not entirely accommodated in the $\mathrm{FC}$-models proposed for their evolution (Figs. 7A,9). However, the mixing among primary magmas produced at distinct depths within the upper mantle, required to justify contrasting REE contents among these rocks in Fig. 9 , is not supported by the behavior of other trace-elements. The same is valid to derive the trachyandesites through the extreme fractionation of a spessartitic magma, or from an amphibole-rich peridotite (Fig. 10C-D). The diversity of shoshonitic-like parental magmas becomes more salient when is also taken into account the Arroio do Jacques monzodiorite, from the Lavras do Sul region (Fig. 9). These constraints allow concluding that the shoshonitic magmatism includes different parental magmas originated from upper mantle sources with a higher GT/CPX ratio, but through a more varied set of genetic processes.

The comparison of the best obtained approximations with the less evolved samples of the two associations shows divergences in the patterns of selected normalized-LILE and HFSE (Fig. 10). In the alkaline rocks, the best result is reached for DA-microdiorites, especially when it is computed the effect of the subsequent fractional
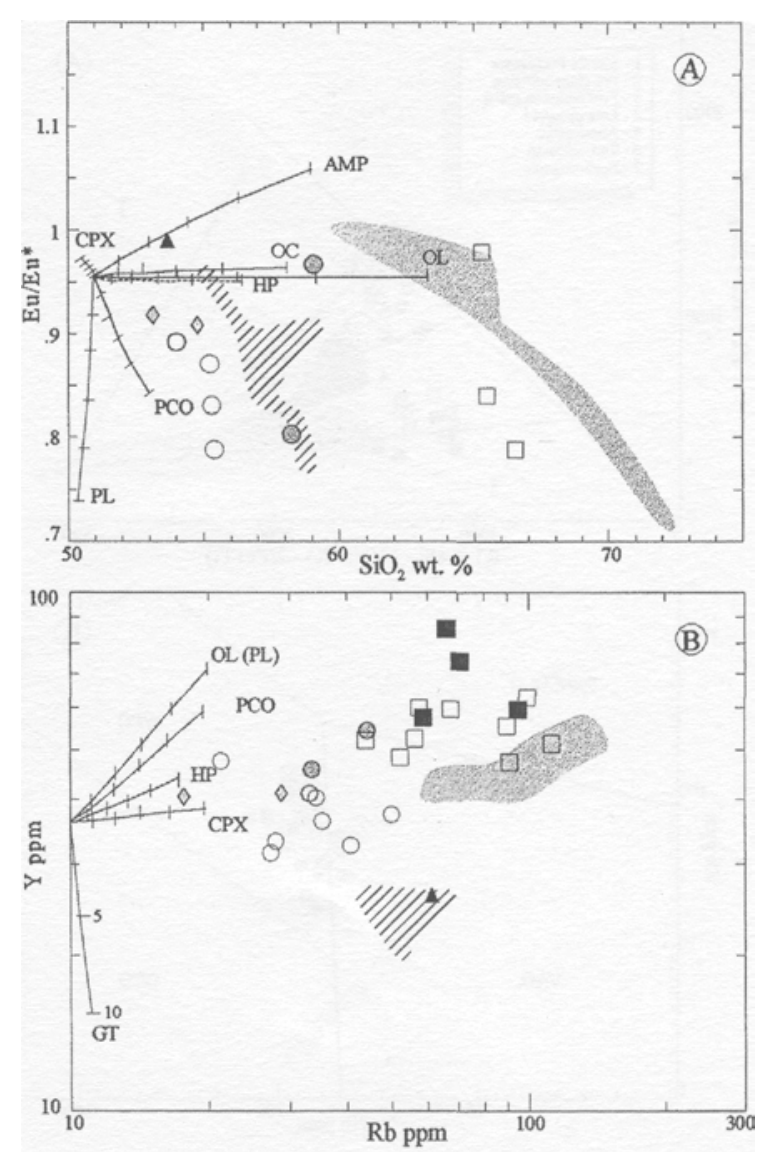

Figure 7 - Eu/Eu* ratio versus $\mathrm{SiO}_{2}-(\mathrm{A})$, and $Y-\mathrm{Rb}-(\boldsymbol{B})$ plots highlighting the contrast between the evolutionary trends for the two associations. Symbols and fields, as in figures 3 and 4. Theoretical vectors are for $50 \%$, with ticks for $10 \%$ crystallization (unless otherwise stated), of simple phases and mineral assemblages as: $\boldsymbol{O C}-41 \%$ augite $+59 \%$ olivine, predicted by Lima \& Nardi (1998) for the evolution from the shoshonitic basic into intermediate lavas; PCO -traditional assemblage composed by $50 \%$ plagioclase $+30 \%$ clinopyroxene $+20 \%$ olivine; and $\boldsymbol{H P}-70 \%$ amphibole $+30 \%$ plagioclase. Partition coefficients compiled by Rollison (1993); for the calculated $\mathrm{SiO}_{2}$ values, it is assumed that plagioclase is An72, and the compositions of olivine and clinopyroxene are taken from Lima \& Nardi (1998). In (A), the vectors are placed at an arbitrary silica value and Eu/Eu* equivalent to the enriched-peridotitic source (L2) considered in the modeling of partial melts in the upper mantle (Fig. 9 and Tab. 3).

crystallization (Fig. 1OA-B). Both more basic alkaline rocks show good convergence for HREE, but flatter LREE/MREE relative to the calculated basaltic melts. In addition, the LRC-rocks are Ba-enriched and show a stronger $\mathrm{Nb}$ and Ti-depletion, whereas $\mathrm{DA}$ shows a lower $\mathrm{Nb}$ and a stronger $\mathrm{Rb}$-depletion. A basaltic melt produced through $2 \%$ of melting of a peridotite with 4-5\% GT is the best approximation for trachyandesites (Fig. 1 OC). The convergence for LREE is good in both more basic shoshonitic rocks, and the divergences are due to lower MREE contents and flatter MREE/HREE. Moreover, despite the variable behavior of some elements, they have a stronger P-Nb-Ti depletion and are $\mathrm{B}$ a, $\mathrm{Zr}$ and $\mathrm{Rb}$-enriched.

In post-orogenic settings, the $\mathrm{Nb}$ and Ti-depletion are usually ascribed to a subduction component, whose origin is on the fluids arising from the dehydration of the subducted slab (e.g. Weaver 1991). This provides the selective enrichment mainly in LILE ( $\mathrm{Sr}, \mathrm{K}, \mathrm{Rb}, \mathrm{Ba}$ and Th) and LREE (e.g. McCulloch \& Gamble 1991), but a roughly similar, though less pronounced effect is also produced by contamination processes (Tarney \& Jones 1994). In the two studied associations, the diversified enrichment/impoverishment factors of some trace elements, such as $\mathrm{Rb}, \mathrm{P}$ and $\mathrm{Nb}$ is one argument against a subduction 

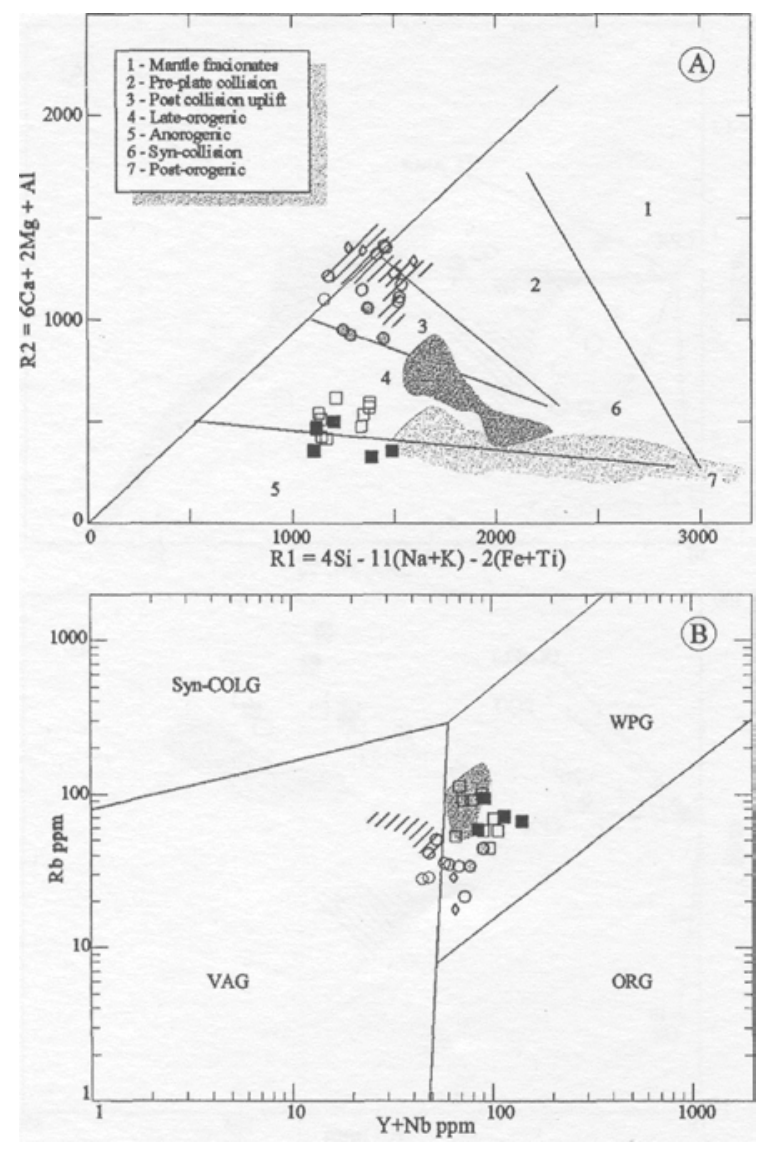

Figure 8 - R1-R2 multicationic - (A), and Rb- $(Y+N b)$ - (B) diagrams for felsic rocks of the two associations; the fields of granite types are respectively from Batchelor \& Bowden (1985) and Pearce et al. (1984).The more basic rocks of both suites are shown for comparison. Symbols and fields, as in figures 3 and 4, and in (B) light gray highlights the field of the Saibro Intrusive Suite, with an alkaline affinity.

component in their source regions. A greater subduction-zone component could have contributed to the origin of shoshonitic parental magmas, which would be consistent with its more magnesian, potassic, calcic and hydrous nature. However, the higher $\mathrm{Zr}$ contents, the relatively lower Ba-enrichment, and the similar values for some incompatible trace-element ratios as $\mathrm{Y} / \mathrm{Nb}$ and $\mathrm{Zr} / \mathrm{Nb}$ of these rocks relative to the alkaline ones, all are features, which argue against such assumption.

The advance provided by the modeling is that the differences in GT/CPX proportions, possibly related to varied depths in the upper mantle sources, can explain the main geochemical characteristics of the parental magmas of the two associations - s.hoshonitic and alkaline. Nonetheless, this alone does not resolve all contrasts between and within them, and other genetic processes are required to account for the differences.

CRUSTAL CONTRIBUTION The search for explaining the genesis of the two associations through the involvement of lower crustal components is necessary because the deficiency of the upper mantle modeling to resolve entirely the geochemical contrasts. This amplifies the possibilities because of the diversity of ages and compositions of crustal segments, and the varied depths and conditions at which interactions between mantle and crustal-derived components take place (Hildreth \& Moorbath 1988). Some possible crustal segments including a wide range of compositions, from mafic-to-felsic, are shown in Table 4 and Fig. 11. Representative samples of the Santa Maria Chico Granulitic Complex (SMCGC) are taken as equivalent to the lower crust in the region. These granulites are strongly depleted in LILE, and include tonalites, trondhjemites, and basic rocks with a tholeiitic affinity (Hartmann 1988,1998). For the present purpose, the two SMCGC-compositional types, mafic and felsic, are separated in

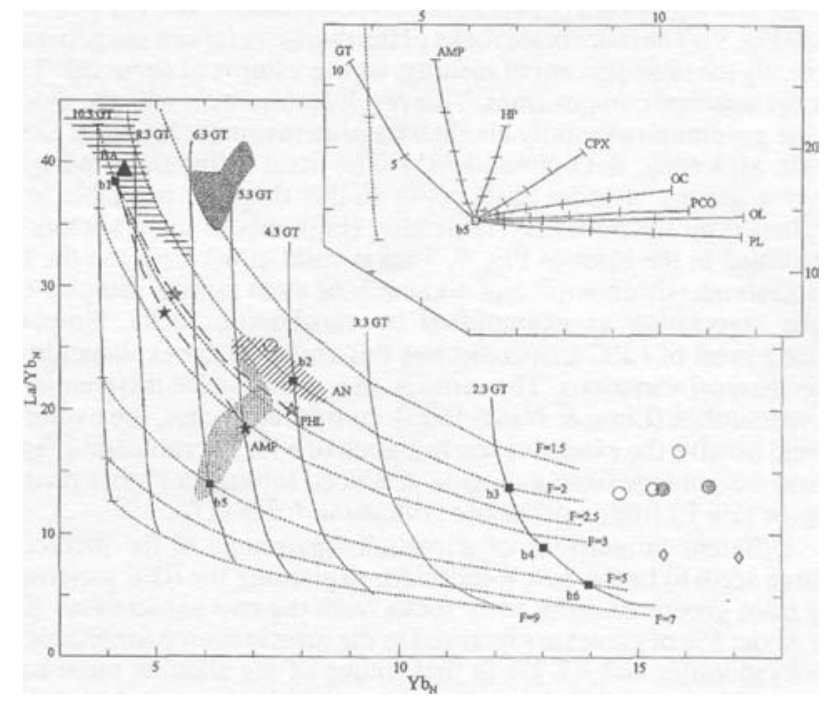

Figure 9 - Normalized La/Yb versus Yb plot for rocks of the two associations. Symbols and fields as in figures 3 and 4; gray crosshatched field for spessartites of the LSSA (Lima \& Nardi 1991; 1998), and horizontal lines for the Arroio do Jacques Monzodiorite of the Lavras do Sul Intrusive Complex. Solid lines show the composition of melts derived from a garnet Iherzolite with variable initial contents of garnet (\% GT is shown above the array); dotted lines for the degree of melting, in terms of the percentage of liquid - F. It is assumed as initial composition the garnet Iherzolite after McKenzie \& O'Nions (1991), which is modified through depletion and next enrichment in incompatible elements to produce an enriched Iherzolite - L2 (see text and table 3 for details). B1, b2, and so on mark the best approximations for the basaltic melts of the two associations. Dashed lines highlight the melts produced through $2.5 \%$ of melting of a Iherzolite with $9.3 \%$ of garnet, whose modal proportions are modified by the addition of $25 \%$ and $50 \%$ (stars) of an anhydrous peridotite, containing respectively amphibole or phlogopite. Normalization factors from Boynton (1984). In the inset, solid lines for fractionated crystallization vectors in basaltic magmas as in figure 7.

three subgroups based on the REE contents and pattern shapes. Only two compositions of each group are considered in the petrogenetic discussion (Table 4). In addition, it also used the average composition of the lower crust after Wedepohl (1995) - CW-I - and Taylor \& McLennan (1985) - CT-I, which is LILE-poorer than that of Wedepohl (1995). The first conclusion is that the parental magmas of both associations cannot result from the bulk assimilation of any referred crustal segments by mantle-derived magmas (Fig. 11). Therefore, simple binary mixing models are not applied, and examining alternatives that include the mixing of basaltic magmas with crustal partial melts is necessary.

The modeling of partial melting of each lower crustal segment was made considering the experimental results obtained on similar compositions at upper mantle (16-10 kbar), and at lower crustal pressures (7-8 kbar) under fluid-absent conditions, and also under conditions of water saturation in the latter case. For more basic compositions, the experimental results obtained by Rapp et al (1991) and Beard \& Lofgren (1991) are used, and after Beard et al (1994) and Skjerlie \& Johnston (1992) for intermediate-to-acid rocks. The modeling was also made for batch melting, taken the residual mineral assemblages as in the experiments at different conditions, and the partition coefficients (Kd) compiled by Rollison (1993). In the assessment of major-element variations and residual minerals of melts derived from felsic granulites, some problems arise considering the experimental results. The initial compositions are too potassic and Ca-poor so that alkali-feldspar and biotite are important as residual phases; so these assemblages were adjusted to the composition of the referred granulites. Partial melting of basic-to-intermediate rocks produced varied liquids, from tonalite/quartz-diorite to trondhjemite and granodiorite, depending mainly on compositional parameters of the source, such as $\mathrm{CaO}, \mathrm{MgO}$ 
Table 3 - Calculated melts from peridotitic source with varied CPX/GT

\begin{tabular}{|r|r|r|r|r|r|r|}
\hline & \multicolumn{3}{c|}{ Garnet lherzolites } & \multicolumn{5}{|c|}{ Calculated basaltic melts } \\
\hline $\mathrm{ppm}(\%)$ & \multicolumn{1}{c|}{$\mathrm{Ll}$} & \multicolumn{1}{c|}{ L2 } & \multicolumn{1}{c|}{ bl } & \multicolumn{1}{c|}{ b2 } & \multicolumn{1}{c|}{ b3 } & \multicolumn{1}{c|}{ b4 } \\
\hline $\mathrm{Rb}$ & 0.062 & 0.989 & 39.0 & 48.5 & 48.49 & 28.0 \\
$\mathrm{Ba}$ & 0.650 & 10.597 & 419.2 & 522.5 & 522.5 & 300.4 \\
$\mathrm{TiO}_{2}$ & 0.170 & 0.211 & 2.27 & 2.52 & 2.58 & 2.24 \\
$\mathrm{Y}$ & 3.180 & 3.031 & 13.8 & 24.6 & 35.74 & 34.5 \\
$\mathrm{Nb}$ & 0.390 & 1.598 & 44.0 & 55.2 & 57.19 & 37.6 \\
$\mathrm{Zr}$ & 7.190 & 10.520 & 148.8 & 189.6 & 206.20 & 165.0 \\
$\mathrm{P}_{2} \mathrm{O}_{5}$ & 0.012 & 0.036 & 0.86 & 1.07 & 1.12 & 0.77 \\
$\mathrm{La}$ & 0.206 & 1.475 & 49.298 & 54.159 & 52.464 & 34.485 \\
$\mathrm{Ce}$ & 0.722 & 3.498 & 103.189 & 106.127 & 101.389 & 71.583 \\
$\mathrm{Nd}$ & 0.815 & 1.925 & 40.407 & 39.033 & 37.178 & 29.526 \\
$\mathrm{Sm}$ & 0.299 & 0.481 & 7.685 & 7.939 & 7.828 & 6.508 \\
$\mathrm{Eu}$ & 0.115 & 0.154 & 2.046 & 2.173 & 2.179 & 1.871 \\
$\mathrm{Gd}$ & 0.419 & 0.490 & 5.434 & 6.390 & 6.737 & 5.869 \\
$\mathrm{Dy}$ & 0.525 & 0.516 & 3.665 & 5.072 & 5.921 & 5.444 \\
$\mathrm{Er}$ & 0.347 & 0.330 & 1.503 & 2.469 & 3.311 & 3.219 \\
$\mathrm{Yb}$ & 0.347 & 0.341 & 0.867 & 1.636 & 2.556 & 2.714 \\
$\mathrm{Lu}$ & 0.054 & 0.054 & 0.104 & 0.205 & 0.339 & 0.376 \\
$\mathrm{Eu} / \mathrm{Eu} *$ & 0.993 & 0.961 & 0.922 & 0.904 & 0.896 & 0.909 \\
$\mathrm{Rb} / \mathrm{Zr}$ & 0.009 & 0.094 & 0.262 & 0.256 & 0.235 & 0.170 \\
$\mathrm{Y} / \mathrm{Rb}$ & 51.290 & 3.065 & 0.354 & 0.507 & 0.737 & 1.232 \\
\hline
\end{tabular}

L1 - garnet Iherzolite, after Mckenzie \& O'Nions (1991; 1995); L2 - calculated garnet Therzolite - previous depletion due to the extraction of $11 \%$ of a basaltic melt, and subsequently enriched with the addition of $7 \%$ of a melt originated by $0.4 \%$ of partial melting.Melts generated from the Iherzolite $\mathrm{L} 2$, taken as variable the $\mathrm{cpx} / \mathrm{gt}$ ratio and the degree of melting: $\mathbf{b l}-9.3 \% \mathrm{GT}$ in the source and $2.5 \%$ of melting; $\mathbf{b 2}-4.3 \% \mathrm{GT}$ and $2 \%$ of melting; b3 $-2.3 \%$ GT and $2 \%$ of melting; $\quad$ b4 $-2.3 \% \mathrm{GT}$ and $3.5 \%$ of melting.

and $\mathrm{FeO}$ (Table 4). The $\mathrm{K}_{2} \mathrm{O} / \mathrm{Na}_{2} \mathrm{O}$ ratio of the produced liquids is roughly proportional to that of the source, but the control of residual amphibole is also prominent regarding to the initial water content (Rapp 1995). As predicted by Rapp (1995), the $\mathrm{Kd}_{\mathrm{AMP}} \mathrm{K}$ changes from $0.2-0.3$ to $0.8-1.0$ in fluid-absent and water saturated conditions, respectively. The compositions Gm3 (high REE basic granulites) and $\mathrm{CW}$-I have elevated $\mathrm{K}_{2} \mathrm{O} / \mathrm{Na}_{2} \mathrm{O}$ ratios enough to the produced partial melts to cause significant modifications in the mantle-derived magmas, especially when fluid-absent melting is considered.

The obtained results provide interesting options to resolve the reported divergences between the calculated mantle melts and parental magmas of the two associations. Distinct melting conditions and compositions of crustal segments can be postulated to adapt the geochemical peculiarities in each case: basic-to-intermediate compositions and more hydrous conditions for shoshonitic parental magmas, whereas for alkaline ones the best results include intermediate-to-felsic compositions and a lower percent of melting under fluid-absent conditions.

The partial melts from crustal segments as Gm3 and CW-I under water saturated conditions are suitable to explain some geochemical contrasts between basaltic trackyandesite and trackyandesite. In addition to the more elevated water content, they would promote the abrupt increase in $\mathrm{Al}_{2} \mathrm{O}_{3}$ and $\mathrm{Sr}$, and decrease in $\mathrm{MgO}$, and also smal variations for $\mathrm{CaO}, \mathrm{K}_{2} \mathrm{O} / \mathrm{Na}_{2} \mathrm{O}, \mathrm{TiO}_{2}, \mathrm{Y}$ and $\mathrm{Eu} / \mathrm{Eu}^{*}$. These melts would also have higher $\mathrm{Ba}$ and lower $\mathrm{FeO}, \mathrm{Nb}, \mathrm{P}$ and $\mathrm{Rb}$ contents, enough to cause modifications in the mantle-derived magmas similar to those of shoshonitic rocks. Furthermore, they would be able to increase the $\mathrm{Yb}_{N}$, and decrease $\mathrm{La} / \mathrm{Yb}_{\mathrm{N}}$ values, matching the effect of decreasing GT/CPX in the mantle sources typical of the evolution of shoshonitic rocks (Fig. 9). On the other hand, the partial melting of the same crustal segments at fluid-absent conditions taken into account an eclogitic residue gives distinct effects, a substantial increase in $\mathrm{La} / \mathrm{Yb}_{\mathrm{N}}$ $\mathrm{Eu} / \mathrm{Eu}^{*}, \mathrm{~K}_{2} \mathrm{O} / \mathrm{Na}_{2} \mathrm{O}, \mathrm{TiO}_{2}$ values, and the decrease in $\mathrm{Al}_{2} \mathrm{O}_{3}, \mathrm{CaO}, \mathrm{Yb}_{\mathrm{N}}$ and $\mathrm{Y}$ content. This last option is interesting to explain some trace-element features of basaltic trachyandesite compared with a mantle-derived magma like that of the trachyandesite, as well as the Arroio do Jacques monzodiorite and the SAGM-parental magmas (Fig. 9). It is possible thus to suggest that the great diversity of compositions in the shoshonitic-like magmas is due to the mixing of mantle-derived basaltic magmas with varied crustal melts, produced from mafic-to-intermediate compositions under a wide range of conditions. Concerning the possible compositions of the lower crust, the main restrictions are the moderate-to-high contents of $\mathrm{Rb}$ and $\mathrm{K}_{2} \mathrm{O} / \mathrm{Na}_{2} \mathrm{O}$, making the $\mathrm{CW}-\mathrm{I}-$ type lower crust the best solution but a higher $\mathrm{Sr}$ abundance like that of Gm3 would also be more appropriate (Table 4).
The crustal melts produced under fluid-absent conditions may be the best alternative as contaminant in the alkaline parental magmas, since the source is relatively $\mathrm{Rb}$ poor. In mixing with basaltic magmas, a lower percent of melts derived from an intermediate LILE-poor lower crust for DA-microdiorite, and from the felsic granulite for LRC-rocks would be required to adjust the major-element variations. In addition, a lower melting degree would also be necessary to resolve the REE behavior in each case. The modifications caused by partial melts produced from $\mathrm{Tl}$ (moderate REE) and T2 (lower REE) felsic granulite reflect the varied REE-HFSE/LILE ratios of the two (Fig. 11); so this would be suitable to explain some geochemical contrasts observed among LRC-more basic rocks. The melts derived from the former type (Tl) have a higher HFSE and REE, lower $\mathrm{Ba}$ and $\mathrm{Rb}$ abundance, and they would be able to increase $\mathrm{Yb}_{\mathrm{N}}$ and decrease $\mathrm{La} / \mathrm{Yb}_{\mathrm{N}}$; the contrary effect would be produced with the T2 composition. However, in the LRC more basic rocks, the assimilation concurrent with the crystallization is also a plausible hypothesis and this become more complex the interpretation of these results.

In this way, diversified conditions of melting and composition of crustal segments imprint a particular signature on each parental magma. This would be then enough to amplify the compositional divergences of mantle-derived magmas, especially regarding to the water content that would have been responsible for the development of the evolutionary trends of the two associations. In addition, the possible lower crust segments involved in the genesis of the shoshonitic magma, contrarily to the alkaline ones, had more distinct compositions than the enclosing SMCGC-granulites.

\section{PETROGENETIC MODEL AND FINAL CONSIDERATIONS}

Apart from the several simplifications necessary to make a geochemical modeling, the contrasts of parental magmas of the two associations seem easily adjusted to the idea that the differences arise from coupled mantle-crust genetic processes. This is particularly relevant to explain some features among the more basic rocks of a same suite, which are hardly explained only by fractional crystallization. More diversified crustal segments and conditions of partial melting are required to produce shoshonitic parental magmas as compared with the alkaline ones. Some solutions of the geochemical modeling imply crustal partial melting at upper mantle pressures, and this could indicate that the interaction between mantle- and crustal-derived melts had occurred at this level; thus, the delamination of crustal segments becomes an attractive option.

The geochemical modeling show that low percents of partial melting $(2-3 \%)$ from a previously depleted upper mantle, subsequently enriched in incompatible elements, is a suitable hypothesis for the generation of basaltic magmas of the two associations. The differences between them can be ascribed to varied garnet/clinopyroxene proportions in the sources. Distinct GT/CPX ratios in the peridotitic source can be though to reflect varied depths, at which the partial melting took place, being shallower for the alkaline magmas. The cause of this variation could be associated with that in the regional tectonic settings, with the progressive change to an extensional regime. A temporal changeover in the two magmatic events, of about 10-40 Ma, would substantiate this assumption. Nevertheless, the predominance of an extensional regime during the genesis of the alkaline magma should imply a deeper level for the melting events in the upper mantle, as compared with that of the shoshonitic rocks. Then, two interesting alternatives for the origin of the two associations may be postulated to incentive futures researches:

1. The effect analogous that of a higher GT/CPX ratio in the mantle source of the shoshonitic parental magmas would be caused mainly by delamination of mafic crustal segments; thus, the transition of the two magmatic events (shoshonitic-alkaline) could be adjusted with the change to an extensional regime during the alkaline magma producing event, which, now, had occurred from a deeper upper mantle source. This would be consistent with a slightly higher degree of previous enrichment of the upper mantle sources for the LRC parental magma.

2 . The progression between the two magmatic events would have resulted from some type of upwelling of the upper mantle sources, instead of changes in the regional tectonic regime. The main argument against this hypothesis, in the light of the presented geochemical modeling, is the similarity in the melting degrees of the mantle sources for both associations. In this case, a higher melting degree would be expected to produce the alkaline magmas from a shallower upper mantle source.

The available geochemical data do not allow an option between the two possibilities, though the first idea is favored by the geochemical modeling. In addition, the first option would support that the two 

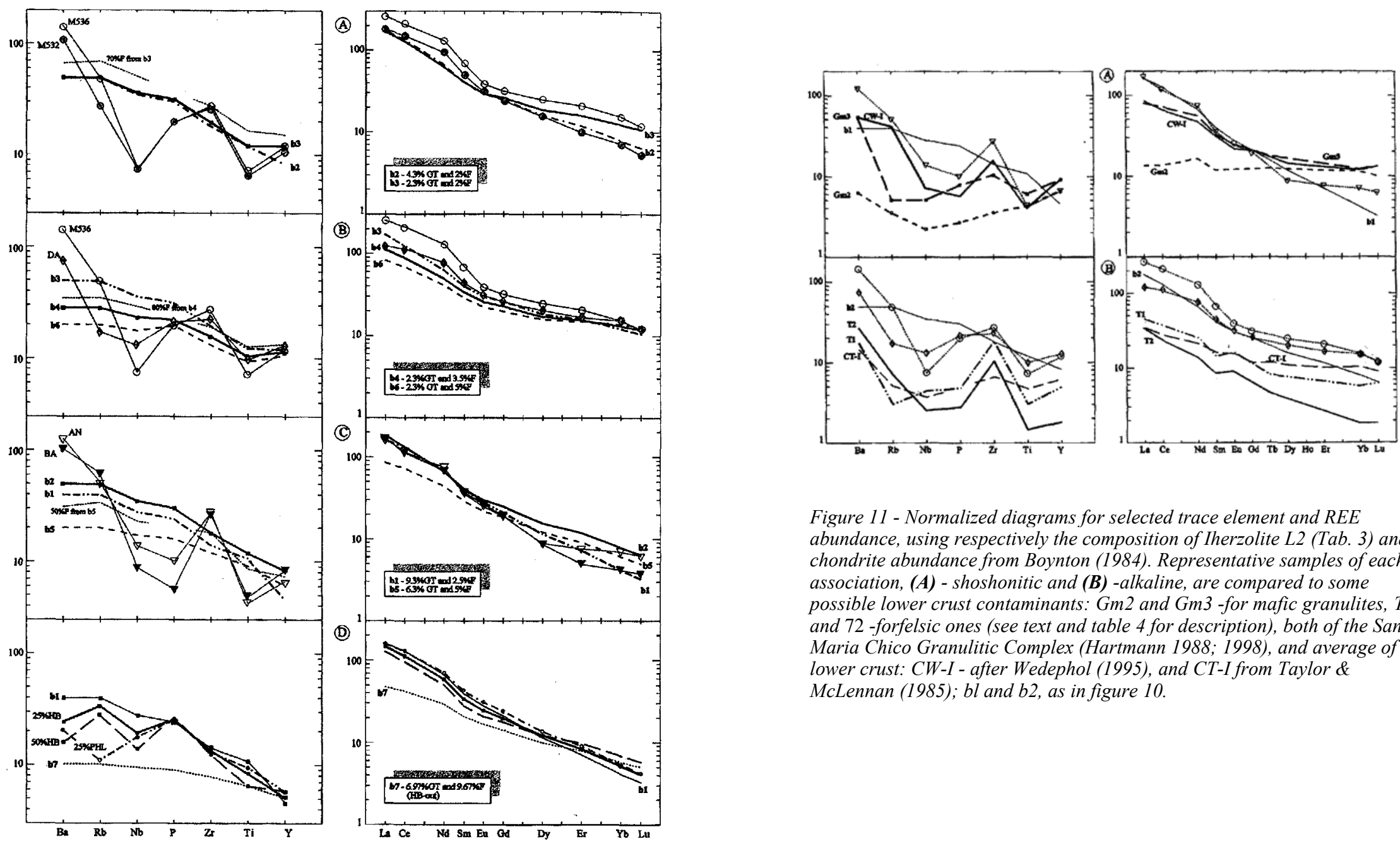

Figure 11 - Normalized diagrams for selected trace element and REE

abundance, using respectively the composition of Iherzolite L2 (Tab. 3) and chondrite abundance from Boynton (1984). Representative samples of each association, $(\boldsymbol{A})$ - shoshonitic and $(\boldsymbol{B})$-alkaline, are compared to some possible lower crust contaminants: Gm2 and Gm3 -for mafic granulites, $T 1$ and 72 -forfelsic ones (see text and table 4 for description), both of the Santo Maria Chico Granulitic Complex (Hartmann 1988; 1998), and average of lower crust: CW-I - after Wedephol (1995), and CT-I from Taylor \& McLennan (1985); bl and b2, as in figure 10.

Figure 10 - Plot of selected trace-element normalized to Iherzolite -12 (Tab. 3) and of chondrite-normalized $R E E$, showing the best results of modeling of upper mantle partial melting to derive parental magmas of the two suites: $(\boldsymbol{A})$ and $(\boldsymbol{B})$ for alkaline, $(\boldsymbol{C})$ for shoshonitic rocks, and in $(\boldsymbol{D})$, it is shown the effect of the addition ofamphibole $(H B)$ and phlogopite (PHL) in a peridotite source, as in figure 9. In (A), (B) and (C), dotted line highlights the possible effect of fractional crystallization in the mantle-derived basaltic magma in each case, where: $70 \% \mathrm{~F}$ from b3 signifies $30 \%$ of crystallization of a PCO assemblage in a basaltic melt b3; $80 \% \mathrm{~F} \mathrm{from}$ b4 - $20 \%$ crystallization of the same assemblage, and $50 \% \mathrm{~F}$ from b5 - $50 \%$ crystallization of a HP assemblage. 
Table 4 - Major and trace element of lower crustal contaminants

\begin{tabular}{|c|c|c|c|c|c|c|}
\hline & Gm2 & Gm3 & CT-I & CW-I & T1 & $\overline{T 2}$ \\
\hline $\mathrm{SiO}_{2}$ & 49.48 & $51 . \overline{25}$ & 54.26 & 58.91 & 67.40 & 71.06 \\
\hline $\mathrm{TiO}_{2}$ & 0.89 & 1.26 & 1.00 & 0.85 & 0.64 & 0.31 \\
\hline $\mathrm{Al}_{2} \mathrm{O}_{3}$ & 14.34 & 15.33 & 16.06 & 15.75 & 15.70 & 15.89 \\
\hline $\mathrm{FeO}_{1}$ & 10.57 & 13.19 & 10.57 & 7.45 & 5.14 & 2.40 \\
\hline $\mathrm{MnO}$ & 0.16 & 0.18 & 0.22 & 0.12 & 0.06 & 0.04 \\
\hline $\mathrm{MgO}$ & 10.01 & 6.13 & 6.28 & 5.31 & 1.27 & 0.91 \\
\hline $\mathrm{CaO}$ & 11.65 & 8.60 & 8.48 & 6.90 & 5.23 & 3.76 \\
\hline $\mathrm{Na}_{2} \mathrm{O}$ & 2.59 & 3.15 & 2.79 & 2.90 & 4.04 & 4.69 \\
\hline $\mathrm{K}_{2} \mathrm{O}$ & 0.22 & 0.63 & 0.34 & 1.60 & 0.35 & 0.83 \\
\hline $\mathrm{P}_{2} \mathrm{O}_{5}$ & 0.09 & 0.27 & -- & 0.20 & 0.17 & 0.10 \\
\hline Total & 100 & 100 & 100 & 100 & 100 & 100 \\
\hline $\mathrm{K}_{2} \mathrm{O} / \mathrm{Na}_{2} \mathrm{O}$ & 0.08 & 0.20 & 0.12 & 0.55 & 0.09 & 0.20 \\
\hline $\mathrm{FeO} /\left(\mathrm{FeO}_{1}+\mathrm{MgO}\right)$ & 0.51 & 0.68 & 0.63 & 0.58 & 0.80 & 0.70 \\
\hline $\mathrm{Rb}$ & 3.50 & 5 & 5 & 41 & 3 & 7 \\
\hline $\mathrm{Ba}$ & 66 & 531 & 150 & 568 & 188 & 287 \\
\hline $\mathrm{Sr}$ & 218 & 776 & 230 & 352 & 370 & 400 \\
\hline$Y$ & 20 & 27 & 19 & 27.20 & 15 & 5.50 \\
\hline $\mathrm{Nb}$ & 3.50 & 8 & 6 & 11.30 & 7 & 4 \\
\hline $\mathrm{Zr}$ & 37 & 109 & 70 & 165 & 192 & 110 \\
\hline$\Sigma$ REE & 31.42 & 127.5 & 60.85 & 182.8 & 65.45 & 42.03 \\
\hline $\mathrm{Eu} / \mathrm{Eu}^{*}$ & 0.988 & 0.960 & 1.123 & 0.843 & 1.47 & 1.393 \\
\hline$Y b_{N}$ & 11.24 & 12.15 & 10.52 & 11.96 & 5.74 & 1.82 \\
\hline $\mathrm{La} / \mathrm{Yb}_{\mathrm{N}}$ & 1.19 & 6.61 & 3.37 & 7.23 & 7.95 & 19.43 \\
\hline Y/Rb & 5.71 & 5.40 & 3.80 & 0.66 & 5.00 & 0.79 \\
\hline
\end{tabular}
compositions: Gm2 - average of samples 12 and 25 (moderate-to-low REE, LILE and HFSE contents a flatter REE pattern); possible produced partial melts: tonalite-to- quartz-diorites. taken as example the experimental results of the sample WR-40 ';Gm3 - average of samples 15 and 19 (higher REE, LILE and HFSE contents and more fractionated REE patterns than Gm2); trondhjemite-togranodiorites as product of paitial melts according to the results of samples FSS or $571^{2}$; - felsic compositions: $\mathrm{Tl}-$ equivalent to the sample 5; and T2 - ave 14 and 28 (T2 has lower REE, higher ( a more fractionated REE patterns than $\mathrm{Tl}$ ); for both the partial melts are granitic taken as example the experimental results of samples HP30 and 75-45 , and Ton ${ }^{4}$; For the two average compositions of lower crust (CT-I after Taylor \& McLennan 1985, and CW-I from Wedephol 1995), granodioritic-to-granitic partial melts are prodeuced like the experimental results of samples 75-164 ' and 557 1 - Rapp et al. (1991); 2 - Beard \& Lofgren (1991); 3 - Beard et al. (1994); and 4 - Skjerlie \& Johnston (1992). associations were in part cogenetic. Nonetheless, there is no sufficient isotopic data to substantiate any conclusion. Whichever the tectonic context, the involvement of partial melts produced from diversified segments of the continental crust are required: a more mafic and deeper, lower crust would be involved in the genesis of the shoshonitic magma, while for alkaline one, the crustal partial melts would be produced from felsic segments, through a lower melting degree and under fluid-absent conditions. Particularly in the LRC, the assimilation of the enclosing SMCGC-granulite during its evolution at a shallower magma chamber would have also occurred.

The differences in the composition of the two parental magmas had been amplified with its further differentiation in magma chambers differently placed at shallower levels in the crust. This is perfectly integrated with the petrological evolution of the Taquarembó volcanicplutonic plateau, as envisaged by Gastai et al. (1998). The shoshonitic magmatic event (SAGM and correlated volcanic rocks) would represent the first episodes, evolved from smaller and deeper-seated magma chambers, whose geochemical characteristics reflect a particular genetic process. These small chambers later become a large shallow silicic magma body, whose evolution involves the higher effectiveness of crystal-liquid fractionation mechanisms and the contamination with granulitic wall rocks. This shallow chamber supplies the magma for the expressive acid volcanism and the small associated intrusive rocks, with alkaline affinity (LRC).

In summary, the integration of coupled mantle-crust genetic processes along with the successive development and evolution of shallow magma chambers seem able to explain the compositional diversity between the suites, shoshonitic-alkaline, in this region. The two are emplaced at the same place and almost at the same time. In a more modest model, the change in the upper mantle sources would have resulted in the increase in volume and in diversity of basaltic magmas at the base of the crust; then, this would induce the successive partial melting of lower crust and the mixing with mantle magma, and consequently would promote the growth and evolution of a shallow and large magma chamber.

Acknowledgments This paper is part of my doctoral dissertation, submitted to the Universidade Federal do Rio Grande do Sul. I am very grateful to the Prof. Dr. Lauro V. S. Nardi, from the Centro de Estudos em Petrologia e Geoquímica, IG/UFRGS. His comments and suggestions to the extended abstract helped to refine my interpretations and to improve the arguments presented. The author also wants to thank to Dr. A.N. Sial, V. P. Ferreira and A. Sá for the opportunity to contribute to the special issue of this journal. The final version of the paper has benefited from the constructive insights of the journal reviewers. This work was supported by grants from FINEP/PADCT 65910 362.00, FAPERGS 93.0422.2 and CNPq 521 302/95-5.

\section{References}

Babinski, M. Chemale Jr., R; Hartmann, L.A.; Van Schmus, W.R.; Silva, L.C. da 1996. Juvenile accretion at 750-700 Ma in southern Brazil. Geol., 24(5):439-442.

Baker, D. R. \& Eggler, D.H. 1987. Compositions of anhydrous and hydrous melts coexisting with plagioclase. augite, and olivine or low Ca-pyroxene from I atm to 8 kbar. Application to the Aleutian centre of Atka. Amer. Mineral., 72(1): 12-28.

Barros, C.E. \& Nardi, L.V.S. 1994. O maciço granítico Santo Antônio, RS: Magmatismo Neoproterozóico de afinidade shoshonítica. Anais Acad. Brás. Ci., 66(4):441-465.

Batchelor, R.A. \& Bowden, P. 1985. Petrogenetic interpretation of granitoid rock series using multicationic parameters. Chem. Geol., 48, 43-55.

Beard, J.S. \& Lofgren, G.E. 1991. Dehydratation melting and water-saturated melting of basaltic and andesitic greenstones and amphibolites at 1,3 and $6.9 \mathrm{~kb}$. Jour. Petrol., 32(2):365-401

Beard, J.S.; Lofgren, G.E.; Sinha, A.K.; Tollo, R.P. 1994. Partial melting of apatite-bearing charnockite, granulite, and diorite: Melt compositions, restite mineralogy, and petrologic implications. Jour. Geophys. Res., 99(B11):21 591-21 603.

Boynton, W.V. 1984. Cosmochemistry of the rare earth elements: meteorite studies. In: Rare Earth Element Geochemistry (Edited by Henderson, P.). Elsevier. Amsterdam. Developments in Geochemistry, 2, p. 63-114

Collins, W.J.; Beams, S.D.; White, A.J.R., Chappell, B.W. 1982. Nature and origin of A-type granites with particular reference to southeastern Australia. Ctmtrib. Mineral. Petrol, 80(2): 189-200.

Davis, J. \& Hawkesworth, C.J. 1994. Early calc-alkaline magmatism in the Mogollon-Datil volcanic field, New Mexico, USA. Jour. Geol. Soc., London, 151, 825-843.

Fernandes, L. A. D.; Menegat, R.; Costa, A. F. U.; Koester, E.; Porcher, C. C.; Tommasi, A.; Kraemer, G.; Ramgrab, G. E.; Camozzato, E. 1995. Evolução tectônica do Cinturão Dom Feliciano no Escudo Sul-rio-grandense: Parte II - uma contribuição a partir das assinaturas geofísicas. Rev. Bras. Geoc., 25(4):375-384.

Fitton, J. G.; James, D. ; Leeman, W.P. 1990. Basic magmatism associated with Late Cenozoic extension in the Western United States. J our. Geoph $\mid$ s. Res., 96, 13696-13711.
Gastai, M.C.P. 1997. Suite Intrusiva Saibro, RS: Avaliação de um modelo petralógico. Unpub. doct. thesis, Universidade Federal do Rio Grande do Sul, Porto Alegre, 365p.

Gastai, M.C.P. \& Lafon, J.M. 1998. Gênese e evolução dos granitóides metaluminosos de afinidade alcalina, porção oeste do Escudo Sul-riograndense: geoquímica e isótopos, Rb-Sre Pb-Pb. Rev. Bras. Geoc., 28(1):9-28.

Gastai, M. C. P.; Schmitt, R. S.; Nardi, L. V. S. 1992. Granitóides da parte centro/sudoeste do Escudo Sul-riograndense. Novos dados e discussão sobre a gênese e tipologia do magmatismo alcalino. Pesquisas, 19(2): 174-182.

Gastai, M.C.P.; Sommer, C.A.; Lafon, J.M.; Barros, C.E. 1998. Neoproterozoic alkaline (over)saturated volcanic-plutonic association of the Taquarembó Plateau, southern Brazil: petrological evolution and genetic link with the shoshonitic magmatism. Precamb. Res. (in press).

Groove, T.L. \& Sisson, T.W. 1991. Water and the role of magnetite in the generation of calc-alkaline rock series. EOS (Abstracts) Transac. Ame. Geophys. Union, 72,292.

Harrison, T. M. \& Watson, E.B. 1984. The behavior of apatite during crustal anatexis: equilibrium and kinetic considerations. Geoch. Cosmoch. Acta, 48(7): 1467-1477.

Hartmann, L.A. 1988. Geoquímica de terras raras e geotermobarometria de granulitos de Dom Pedrito e Luis Alves, no extremo sul do Brasil. Geoch. Brasil., 2,1-14.

Hartmann, L.A. 1998. Deepest exposed crust of Brazil - geochemistry of Paleoproterozoic depleted Santa Maria Chico granulites. Gondwana Res. (in press).

Hildreth, W. \& Moorbath, S. 1988. Crustal contributions to arc magmatism in the Andes of Central Chile. Contrih. Mineral. Petrol., 38,455-489.

Irvine, T.N. \& Baragar, W.R. A. 1971. A guide to the chemical classification of the common rocks. Canadian Jour. Earth Sc., 8, 523-548.

Jaques, A.L. \& Green, D.H. 1980. Anhydrous melting of peridotite at $0-15 \mathrm{~kb}$ and the genesis of tholeiitic basalts. Contrih. Mineral. Petrol., 73, 287-310

Johnson, M.C. \& Rutherford, M.J. 1989. Experimentally determined conditions in the Fish Canyon Tuff, Colorado, Magma Chamber. Jour. Petrol., 30(3):711-737.

Le Maitre, R.W. 1989. A classification of igneous rocks and glossary of terms: recommendations of the International Union ofGeological Sciences subcommission on the systematic ${ }^{\wedge}$ of igneous rocks. Oxford, Blackwell Sci. Pub., 193p. 
Leaf, P.T.; Thompson, R.N.; Morrison, M.A.; Hendry, G.L; Dickin, A.P. 1991. Alkaline hybrid mafic magmas of the Yampa area, NW Colorado, and their relationship to the Yellowstone mantle plume and lithospheric mantle domains. Contrib. Mineral.Petrol., 107(3):310-327.

Lima, E.F. de \& Nardi, L.V.S. 1991. Os lamprófiros espessartíticos da associação shoshonítica de Lavras do Sul, RS. Geoch. Brasil., S, 117-131.

Lima, E.F. de \& Nardi, L.V.S. 1998. The Lavras do Sul shoshonitic association, southernmost Brazil: implications for the origin and evolution of shoshonitic magmatism. Jour. South Amer. Earth Sci., 11 (1):67-77.

Lindsley, D.H.; Frost, B.R.; Andersen, D.J.; Davidson, P.M. 1990. Fe-Ti oxide-silicate equilibria: assemblages with orthopyroxene. In: Fluid-mineral Interactions: A tribute to H.P. Eugster (Edited by Spencer, R.J. and Chou, I-Ming.).Geochem. Soc., Sp. Public., 2, 103-119.

Lipman, P. W. 1984. The roots of ash flow calderas in Western North America: windows into the tops of granitic batholiths. Jour. Geophys. Res., 89, $8801-8841$.

Luhr, J. F. 1997. Extensional tectonics and the diverse primitive volcanic rocks in the Western mexican Volcanic Belt. Can. Mineral., 35(2):473-500.

McCulloch, M.T. \& Gamble, J.A. 1991. Geochemical and geodynamical constraints on subduction zone magmatism. Earth Plan. Sci. Letters, 102(3/4):358-374.

McKenzie, D. \& O'Nions, R .K., 1991. Partial melt distributions from inversion of rare element concentrations. Jour. Petrol., 32,1021-1091.

McKenzies, D. \& O'Nions, R. K. 1995. The source regions of ocean island basalts. Jour. Petrol., 36(1): 133-159.

Meen, J.K. 1987. Formation of shoshonites from calc-alkaline basaltic magmas: geochemical and experimental constraints from the type locality. Contrib. Mineral. Petrol., 97, 333-351.

Nardi, L.V.S. \& Bonin, B. 1991. Post-orogenic and non-orogenic alkaline granite associations: The Saibro intrusive suite, southern Brazil. A case study. Chem. Geoi, 92(1/2): 197-211.

Nelson, S.A. \& Livieres, R.A. 1986. Contemporaneous calc-alkaline and alkaline volcanism at Sanganguey volcano, Nayarit, Mexico. Geol. Soc. Amer. Bull., 97(7):798-808.

Pearce, J.A.; Harris, N.B.W.; Tindle, A.G. 1984. Trace element diagrams for the tectonic interpretation of granitic rocks. Jour. Petrol. 25(4):956-983.

Rapp, R.P. 1995. Amphibole-out phase boundary in partially melted metabasalt, its control over liquid fraction and composition, and source permeability. Jour. Gei $>$ ph $\mid$ s. Res., 100(B8):15 601-15 610.
Rapp, R.P.; Watson, E.B.; Miller, C.F. 1991. Partial melting of amphibolite/eclogite and the origin of Archean trondhjemites and tonalites. Precamh. Res., 51(1/4): 1-25.

Remus, M.V.D.; McNaughton, N.J.; Hartmann, L.A.; Fletcher, I.R. 1997. Zircon SHRIMP $\mathrm{U}-\mathrm{Pb}$ and Nd isotope data of granitoids of the São Gabriel Block, southern Brazil: evidence for an Archaean/Paleoproterozoic basement. In: Ferreira, V.P. \& Sial, A.N. (eds.), Second International Symposium on Granites and Associated Mineralizations, Salvador, Extended Abstract and Program...p p. 271-272.

Rollison, H.R. 1993. Using geochemical data: evaluation, presentation, interpretation. Logman Scientific \& Technical. Singapore. $352 \mathrm{p}$.

Skjerlie, K. P. \& Johnston, A.D. 1992. Vapor-absent melting at $10 \mathrm{kbar}$ of a biotite- and amphibole-bearing tonalitic gneiss; Implications for the generation of A-type granites. Geol., 20, 263-266.

Sommer, C. A. 1994. O vulcanismo ácido alcalino da porção sul do platô do Taquarembó, Dom Pedrito, RS. Unpub. M.Sc. dissert., Univ. Federal do Rio Grande do Sul, Porto Alegre, 149p.

Sommer, C. A.; Lima, E.F. de; Nardi, L.V.S. 1993. O vulcanismo ácido alcalino no Plato do Taquarembó, Dom Pedrito, RS. Simpósio International del Neoproterozóico-Cámbrico en la Cuenca del Plata, 1, Uruguay, Extended abstract $\mathrm{n}^{\circ} 40,5 \mathrm{p}$.

Szubert, E.G.; Castro, V.H.S. de; Grazia, C.A.; Andriotti, J.L.S.; Shintaku, I. 1976. Projeto cobre nos corpos básicos-ultrabásicos e efusivas do Rio Grande do Sul (relatório preliminar). DNPM/CPRM.

Tarney, J. \& Jones, C.E. 1994. Trace element geochemistry of orogenic igneous rocks and crustal growth models. Jour. Geol. Soc., London, 151, 855-868

Taylor, S.R. \& McLenann, S.M. 1985. The Continental Crust: Its Composition and Evolution. Oxford. Blackwell Scientific Publications, 312p

Wallace, P. J. \& Carmichael, I.S.E. 1992. Alkaline and calc-alkaline lavas near Los Volcanes, Jalisco, Mexico: Geochemical diversity and its significance in volcanic arcs. Contrib. Mineral. Petrol., Ill, 423-439.

Weaver, B.L. 1991. The origin of ocean island basalt end-member compositions: trace element and isotopic constraints. Earth Planet. Sci. Letters, 104, 381-397.

Wedepohl, K.H. 1995. The composition of the continental crust. Geoch. Cosmoch. Acta, 59(7): 1217-1232.

Manuscrito A-1055

Recebido em 20 de Janeiro de 1998 Revisão da autora em 15 de agosto de 1998 Revisão aceita em 20 de setembro de 1998 